OPEN ACCESS

Edited by:

Leon M. Hermans,

IHE Delft Institute for Water

Education, Netherlands

Reviewed by:

Melissa Haeffner,

Portland State University,

United States

Anamika Barua,

Indian Institute of Technology

Guwahati, India

*Correspondence:

Panthea Pouramin

pantheapouramin@gmail.com

Specialty section: This article was submitted to Water and Human Systems, a section of the journal

Frontiers in Water

Received: 31 December 2019 Accepted: 17 March 2020

Published: 15 April 2020

Citation:

Pouramin P, Nagabhatla $N$ and Miletto M (2020) A Systematic Review

of Water and Gender Interlinkages: Assessing the Intersection With

Health. Front. Water 2:6. doi: 10.3389/frwa.2020.00006

\section{A Systematic Review of Water and Gender Interlinkages: Assessing the Intersection With Health}

\author{
Panthea Pouramin $^{1 *}$, Nidhi Nagabhatla ${ }^{1,2}$ and Michela Miletto ${ }^{3}$ \\ ${ }^{1}$ United Nations University Institute for Water, Environment and Health (UNU INWEH), Hamilton, ON, Canada, ${ }^{2}$ School of \\ Geography and Earth Science, McMaster University, Hamilton, ON, Canada, ${ }^{3}$ United Nations Educational, Scientific and \\ Cultural Organization World Water Assessment Programme (UNESCO WWAP), Perugia, Italy
}

Background: Significant developmental challenges in low-resource settings limit access to sustainable water, sanitation, and hygiene (WASH). However, in addition to reducing human agency and dignity, gendered WASH inequities can also increase disease burden among women and girls. In this systematic review, a range of challenges experienced by women relating to inadequate WASH resources are described and their intersection with health are explored. We further assess the effectiveness of interventions in alleviating inequalities related to the Sustainable Development Goals (SDGs) three (health), five (gender), and six (water).

Methods: We searched the MEDLINE database to identify research articles related to water (i.e., WASH), gender, and sustainability. An analysis of both observational and interventional studies was undertaken. For each study, content analysis was performed to identify the relevant WASH, gender, and health related outcomes, and the main conclusions of the study.

Results: Key themes from our search included that women and girls face barriers toward accessing basic sanitation and hygiene resources, including a lack of secure and private sanitation and of Menstrual Hygiene Management (MHM) resources. In total, $71 \%$ of identified studies reported a health outcome, suggesting an intersection of water and gender with health. Half of the research studies that included a health component reflected on the relationship between WASH, gender, and infantile diseases, including under-5 mortality, waterborne parasites, and stunting. In addition, we found that women and girls, as a result of their role as water purveyors, were at risk of exposure to contaminated water and of sustaining musculoskeletal trauma. A limited number of studies directly compared gender differences in accessing WASH resources, and an even smaller fraction ( $N=5,8.5 \%$ ) reported sex-disaggregated outcomes. Educational, infrastructural, and programmatic interventions showed promise in reducing WASH and health outcomes. Indeed, infrastructural WASH interventions can be successful if long-term maintenance is ensured.

Conclusions: Significant WASH inequities in women and girls further manifest as health burdens, providing strong evidence that the water-gender-nexus intersects with health. 
Thus, addressing gender and water inequities holds the potential to alleviate disease burden and have a significant impact on achieving the SDGs, including SDG three, five, and six.

Keywords: water, gender, health, sustainable development goals, WASH, hygiene

\section{INTRODUCTION}

\section{Rationale}

Water is necessary for life, and for numerous derived essential applications ranging from industry, agriculture, drinking, sanitation, and hygiene. The Joint Monitoring Program (JMP) describes how among the least developed countries, 35\% lacked access to basic water needs (i.e., water from an improved water source which can be retrieved within a $15 \mathrm{~min}$ round trip), 65\% lacked access to basic sanitation (i.e., a toilet or latrine which protects against soil leaching by contaminants), and $73 \%$ lacked access to basic hygiene (i.e., a handwashing facility with soap and water) (WHO and UNICEF, 2019). These staggering statistics point to a lack of critical human development, especially for the vulnerable and marginalized populations. Recognizing the importance of accessing water, the Sustainable Development Goals (SDGs), as demonstrated by SDG 6 which emphasizes "clean water and sanitation" (targets 6.1 and 6.2), outline indicators for ensuring sustainable and equitable access to water for all. Broadly, these SDG targets focus on providing ubiquitous access to sustainable water, basic sanitation and hygiene (WASH) to redress deficiencies prevalent among low- and middle- income countries (LMICs) and populations living in vulnerable situations (Nagabhatla et al., 2019).

It is paramount to recognize that inequities in accessing WASH resources are further exacerbated among specific populations. For example, rural populations and women represent marginalized groups who are unduly encumbered by poor WASH practices or face additional challenges in accessing WASH resources (WHO and UNICEF, 2019). Women and girls disproportionately serve as water purveyors, collecting water in eight of 10 households, and as such, often face the burdens of needing to transit long distances to retrieve water (WHO and UNICEF, 2017). Moreover, women and girls require additional resources to address their menstrual hygiene management (MHM) needs. According to the 2017 JMP report (WHO and UNICEF, 2017), MHM is stated as, “...using a clean menstrual management material to absorb or collect menstrual blood, that can be changed in privacy as often as necessary for the duration of a menstrual period, using soap and water for washing the body as required, and having access to safe and convenient facilities to dispose of used menstrual management materials." MHM is instrumental in progressing women's and girls' ability to manage their menstrual periods safely and with dignity; thereby, allowing them to participate in school, work, and other activities (Sommer et al., 2016). In general, WASH-related challenges among women are often exacerbated by women's general reduced agency in low-resource settings and need to be appropriately addressed to ensure gender equity objectives.

Despite these gender-related deficiencies, research assessing the intersection between gender and water is severely lacking and remediating gender-water inequities will require targeted resources to fill in the gaps. For example, the 2014 JMP report did not collect sex-disaggregated data, and in 2015, it reported obstacles in collecting sex-disaggregated data (Fletcher and Schonewille, 2015). The 2014 UN-Water Global Analysis and Assessment of Sanitation and Drinking-Water survey also entirely excluded sex-disaggregated data reporting (Fletcher and Schonewille, 2015). In 2019, the World Water Development Report likewise highlights this gap, more specifically related to WASH and MHM related challenges for populations living in vulnerable situations (Nagabhatla et al., 2019).

There are further interlinkages existing between water, gender, and health- worsening WASH-inequities among women cause associated health burdens. Among other burdens, poor WASH practices elevate the risk for waterborne diseases, including for example cholera, a bacterial infection and transmitted by contaminated water and poor sanitation and hygiene practices (Mahamud et al., 2011; Fletcher and Schonewille, 2015). Given the role of women in water provisioning for households, they are at an increased risk of exposure to transmission and contraction of disease (World Health Organization, 2011). Likewise, urinary tract infections (UTI's) as a result of poor MHM practices, can result in school absences and an overall reduced education (Sommer et al., 2016).

In this way, the SDGs are uniquely interconnected, particularly with respect to accessing water, as the SDG 6 Synthesis Report (2018) reflects- "Water resources are embedded in all forms of development (e.g., food security, health promotion, and poverty reduction), in sustaining economic growth in agriculture, industry and energy generation, and in maintaining healthy ecosystems" (United Nations, 2018). Despite this, a detailed understanding of the interlinkages between water and gender is lacking. Moreover, given that the health burdens associated with poor WASH can disproportionately entangle women, the water-gender interlinkages with health need to be carefully examined and, subsequently, integrated into policies.

One step toward helping fill this gap has been the work completed by United Nations Educational, Scientific and Cultural Organization (UNESCO) in developing the Water and Gender toolkit for collecting sex-disaggregated data in the water sector [World Water Assessment Programme (UNESCO WWAP), 2019]. The updated toolkit introduces a set of new indicators to better elucidate how women and girls experience inequities related to accessing or making decisions regarding water and water-related tasks [World Water Assessment Programme (UNESCO WWAP), 2019]. However, more work is needed to understand the landscape of the water-gender nexus as it has currently been described in the literature, and to interrogate its intersection with health. 


\section{Objectives}

To survey observational and interventional studies of adults and children conducted globally to identify the range of WASH challenges experienced by women; identify major health burdens associated with lacking WASH provisions, and specifically within women; identify key themes of WASH interventions for addressing burdens associated with the water, gender, and health interlinkages.

\section{Research Question}

This research aimed to interrogate the question, do WASH based deficiencies disproportionately burden women? If so, do these deficiencies manifest through augmenting health burdens among women and girls?

\section{METHODS}

\section{Study Design}

We conducted a systematic review using a broad-based content analysis through the PRISMA guidelines. This approach was adopted for an investigation that aimed to include key highlights identified by each study with respect to the water-gender interlinkages and its intersection with health.

\section{Participants}

For each paper, the population of women was considered and was subdivided into three categories: (1) girl/adolescent, (2) pregnant/maternal women, (3) household/adult women. WASH was categorized with respect to whether it addresses (1) water, (2) sanitation, (3) hygiene, or (4) MHM. Health outcomes were categorized based on the disease or the burden described. For each WASH and health outcome, relevant outcomes relating to poor WASH accessibility, or health were described. Where available, an assessment of whether the study directly compares gender, and whether poor WASH or health outcomes were gender specific was considered. In studies that focused solely on women, whether specific gender-based challenges are identified and documented was also noted.

\section{Search Strategy}

A two-phase strategy was adopted to search the literature for documents/papers mining. A comprehensive keyword search of the primary literature was conducted using the MEDLINE database. After excluding irrelevant papers, in phase 2, a broad content analysis was adopted to identify relevant, and broadreaching WASH and health data information. A single search approach was used to first comprehensively identify articles related to the water-gender nexus. Subsequently, these articles were analyzed to determine whether a health component was present. In short, a selection criterion was outlined and adopted to shortlist the papers.

\section{Phase 1: Search Strategy and Aggregation of Data and Information}

A systematic review of MEDLINE publications via PubMed was used. Search terms surrounding three categories [gender, water, and sustainability], were incorporated in the search query.

\section{Records Identified}

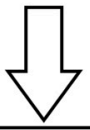

Non-original articles ( $\mathrm{N}=77$ excluded)

Non-human populations ( $\mathrm{N}=36$ excluded)

Could not be access ( $\mathrm{N}=2$ excluded)

No WASH outcomes ( $\mathrm{N}=64$ excluded)

No gender component ( $\mathrm{N}=21$ excluded)

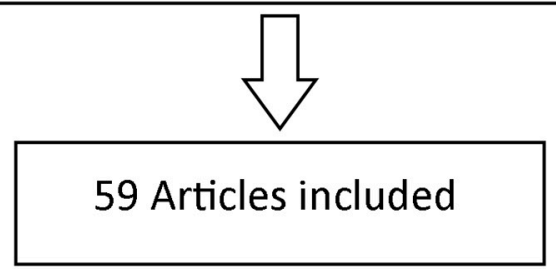

FIGURE 1 | A flowchart of our search strategy and inclusion approach adopted in the systematic review.

For each category, terms spanning multiple dimensions of that theme and derived words were searched. For instance, the search terms for gender included: woman, women, female, sex, gender, girls, girl, gender equality, gender gap, women's empowerment, and women empowerment. In addition, for water: WASH, water sanitation and hygiene, sanitation, clean water, safe water, hygiene, water access, water security, water availability, water collection, water management, fetching water, water fetching, drinking water, water sources, and water source. The search terms for sustainability included: sustainable development goal, sustainable development goals, sustainable development, SDG, SDGs, sustainability, and sustainable.

Our inclusion criteria included observational studies and clinical trials that utilized a quantitative, qualitative, or mixedmethods design; was available in English; contained a WASH outcome; and explicitly considered a gendered outcome (i.e., in women or girls, or gender/sex differences). Exclusion criteria included studies not focused on humans, that did not provide primary data or analysis (i.e., commentaries, systematic reviews, literature reports) and did not consider a population (i.e., case reports). Figure 1 provides a flowchart of the methodological approach. 


\section{Phase 2: Criteria Based Analysis}

For each of the selected research papers, data were collected describing the study design, location, population, WASH outcomes, health outcomes, whether the study was sex-disaggregated, and the key highlights. For interventional studies, information describing the intervention were examined. Sex-disaggregated data was defined as data whereby indicators for men and women are separately provided.

\section{Assessing Risk of Bias}

We assessed the risk for bias in individual studies using a previously validated adaptation of the Cochrane risk of bias instrument (Akl et al., 2012). Bias is assessed based on the response options "definitely yes or no" or "probably yes or no" to criteria highlighted separately for cross-sectional, cohort, and randomized control trials (Supplemental Tables 1-3). Questions include for example, "Is the source population representative of the population of interest?" where affirmative answers indicate less bias, and negative responses indicating greater bias. Information regarding the risk of bias tools used can be found at https:// www.evidencepartners.com/resources/methodological-

resources.

In brief, cross-sectional studies with low bias are characterized by the demonstrated use of a valid sampling strategy (e.g., simple sampling, cluster sampling, etc.); an adequate participant response/inclusion rate; little reported missing data; the inclusion of relevant outcome measures; and validation of the data collection method (e.g., pilot testing, previously validated approach).

Cohort studies with low bias are characterized by evidence that individual cohorts are drawn from a common underlying population (i.e., similar communities which deviate mainly due to exposure to the factor of interest); use satisfactory data collection modalities for relevant factors, outcomes, and confounds; ensure that baseline levels of the outcome of interest are absent or equally low; ensure minimal differences in other confounding variables, or, use appropriate statistical methods to account for confounds (e.g., matching, or regression); use an appropriate follow-up strategy with a high degree of participant retention; are not impacted by the differential exposure to other interventions/ameliorating strategies (e.g., free education is present in only one community).

Randomized control trials with low bias ensure the random allocation of patients to the respective treatment groups (e.g., simple random stratification, matched stratification); that the randomization procedure is concealed; adequate blinding of participants, healthcare providers, data collectors, outcome assessors, and data analysts; a low loss to follow-up; report all pre-determined outcome measures (e.g., do not selectively withhold results, or statistical analyses); and was generally conducted in a statistically sound, valid, and reliable manner (e.g., use appropriate data collection instruments, have appropriate controls).

\section{RESULTS}

\section{Study Selection and Characteristics}

This analysis identified 59 research articles from 30 countries published between 1993 and 2019. Close to half of the publications conducted analyses in Sub-Saharan Africa with Kenya $(N=7)$ and Nigeria $(N=5)$ representing the most frequently studied countries. Table 1 describes 46 identified observational studies included in the analysis, while Table 2 describes 13 identified interventional studies. Primarily, WASH studies focused on measuring access to water (74\%), followed by access to sanitation (54\%), hygiene (10\%), and MHM (7\%). As well, close to half of studies (46\%) focused exclusively on the experience of women and girls and did not consider impacts on men. Only five publications $(8.5 \%)$ reported some sex-disaggregated outcomes.

\section{Synthesized Findings}

\section{Women Are the Primary Water Purveyors, Particularly} in the Developing Regions of the World

Largely, the identified observational studies (Table 1) emphasized issues in accessing clean water among women and girls, and described that a lack of clean water and water resources negatively contributed to women and girl's health and quality of life (Doherty et al., 2007; Bornman et al., 2012; Sato et al., 2016; Gaspar et al., 2017; Vos et al., 2017; Angoua et al., 2018; Prado et al., 2019). Studies which considered gender likewise revealed a lack of access to improved water for both men and women alike (Ugbomoiko et al., 2009; Al-Delaimy et al., 2014; Atalabi et al., 2016; Holvoet et al., 2016; Akombi et al., 2017; Baker et al., 2018). Few studies directly compared whether access to water differed as a result of a gender. However, Bisung and Elliott (2018) showed that female-headed households had reduced access to water security (Bisung and Elliott, 2018). Moreover, within a household, there was substantial evidence that women as the primary carriers of water with prevalence estimates ranging from 61 to 79\% (Hunter, 2006; Bornman et al., 2012; Holvoet et al., 2016; Geere et al., 2018). Indeed, the presence of a wife in the household significantly increased the likelihood of having access to clear water (Angoua et al., 2018). Mean travel times for fetching water were as high as $54 \mathrm{~min}$ (Holvoet et al., 2016). Consequently, poor access to water at a household level disproportionately impacts women and girls who are commonly responsible for securing water.

\section{Women Face Unique WASH and MHM Challenges}

A multitude of studies focused on women and girls and demonstrated that women practiced poor sanitation, hygiene, and MHM practices, largely due to lacking resources. Sanitation facilities were commonly cited to not be safe, clean, and accessible (Kwiringira et al., 2014; Sato et al., 2016; Khan et al., 2017; Aluko et al., 2018; Angoua et al., 2018; Dendup et al., 2018; Desalegn et al., 2018; Njuguna, 2019; Winter et al., 2019). Basic needs, such as soap and washing facilities, and hygienic products, such as toothpaste were documented as hygiene barriers (Budhathoki et al., 2018; Lubon et al., 2018). Moreover, women and girls often cited that critical challenges 
TABLE 1 | Observational studies from the systematic review to assess the water-gender nexus (focused on WASH) with the inclusion of health outcomes.

\begin{tabular}{|c|c|c|c|c|c|c|c|c|}
\hline References & Country & Study design & Sample size & Health component & WASH outcome & Gender outcome & $\begin{array}{l}\text { Sex } \\
\text { disaggregated }\end{array}$ & Conclusion \\
\hline $\begin{array}{l}\text { Acheampong et al. } \\
\text { (2017) }\end{array}$ & $\begin{array}{l}\text { High, low } \\
\text { and middle- } \\
\text { income } \\
\text { countries }\end{array}$ & Modeling & 109 countries & Under-five mortality & $\begin{array}{l}\text { Access to an } \\
\text { improved water } \\
\text { source, improved } \\
\text { sanitation }\end{array}$ & $\begin{array}{l}\text { Considered the } \\
\text { impact of female } \\
\text { employment and } \\
\text { female literacy rates. }\end{array}$ & No & $\begin{array}{l}\text { Improved access to drinking water } \\
\text { and sanitation correlated with a } \\
\text { reduced under- } 5 \text { mortality rate; } \\
\text { female metrics had no effect. }\end{array}$ \\
\hline $\begin{array}{l}\text { Acheampong et al. } \\
\text { (2018) }\end{array}$ & Africa & Cross-sectional & 43 countries & Under-five mortality & $\begin{array}{l}\text { Access to an } \\
\text { improved water } \\
\text { source, improved } \\
\text { sanitation }\end{array}$ & $\begin{array}{l}\text { Considered female } \\
\text { employment and } \\
\text { literacy rates. }\end{array}$ & No & $\begin{array}{l}\text { Access to improved water and } \\
\text { sanitation reduced under-five } \\
\text { mortality, and engendered variables } \\
\text { had no effect. }\end{array}$ \\
\hline Ahmed et al. (2016) & Global & Mixed methods & 10 countries & Under-five mortality & $\begin{array}{l}\text { Access to an } \\
\text { improved water } \\
\text { source, and } \\
\text { sanitation. }\end{array}$ & $\begin{array}{l}\text { Levels of female } \\
\text { education and } \\
\text { employment. }\end{array}$ & No & $\begin{array}{l}\text { Among others, policies which } \\
\text { increased investment in girl's } \\
\text { education and improved access to } \\
\text { water, sanitation, and hygiene were } \\
\text { implemented in countries successful } \\
\text { in reducing the under- } 5 \text { mortality and } \\
\text { thus, was attributed to their success. }\end{array}$ \\
\hline Aiemjoy et al. (2017) & Ethiopia & Cross-sectional & $\begin{array}{l}278 \text { households, } \\
15 \text { focus group } \\
\text { discussions }\end{array}$ & $\mathrm{N} / \mathrm{A}$ & $\begin{array}{l}\text { Access to a } \\
\text { household latrine }\end{array}$ & $\begin{array}{l}\text { Assessed } \\
\text { differences between } \\
\text { male and female } \\
\text { headed households. }\end{array}$ & No & $\begin{array}{l}\text { Male-headed households were } \\
\text { 3.5-fold more likely to use latrines } \\
\text { than households with female heads. } \\
\text { Women preferred not to use latrines } \\
\text { and considered them scary. Having } \\
\text { children in school improved the odds } \\
\text { of having a latrine by } 2 \text {-fold. } \\
\text { Economic indicators did not serve as } \\
\text { a barrier. }\end{array}$ \\
\hline Akachi et al. (2018) & $\begin{array}{l}\text { Sub- } \\
\text { Saharan } \\
\text { Africa }\end{array}$ & Longitudinal & 562, 896 children & Under-five mortality & $\begin{array}{l}\text { Access to an } \\
\text { improved water } \\
\text { source, and } \\
\text { in-house sanitation } \\
\text { facilities; } \\
\text { handwashing } \\
\text { frequency }\end{array}$ & $\begin{array}{l}\text { Considered } \\
\text { maternal factors. }\end{array}$ & No & $\begin{array}{l}\text { After confound adjustment, } \\
\text { high-quality water and sanitation had } \\
\text { no effect on under- } 5 \text { mortality. Female } \\
\text { education reduced under- } 5 \text { mortality. }\end{array}$ \\
\hline Akombi et al. (2017) & Nigeria & Cross-sectional & $\begin{array}{l}24,529 \text { children } \\
\text { aged 0-59 } \\
\text { months old. }\end{array}$ & Child stunting & $\begin{array}{l}\text { Access to an } \\
\text { improved water } \\
\text { source }\end{array}$ & $\begin{array}{l}\text { Compared gender } \\
\text { differences. }\end{array}$ & No & $\begin{array}{l}\text { Four in } 10 \text { used water from an } \\
\text { unimproved source. Male children } \\
\text { were more likely to be stunted in } \\
\text { comparison to females for both 0-23 } \\
\text { months and 0-59 months old. } \\
\text { Access to an improved drinking water } \\
\text { decreased the odds of stunting by } \\
\sim 30 \% \text { in children aged 0-59 months } \\
\text { old. }\end{array}$ \\
\hline
\end{tabular}


TABLE 1 | Continued

\begin{tabular}{|c|c|c|c|c|c|c|c|c|}
\hline References & Country & Study design & Sample size & Health component & WASH outcome & Gender outcome & $\begin{array}{l}\text { Sex } \\
\text { disaggregated }\end{array}$ & Conclusion \\
\hline Al-Delaimy et al. (2014) & Malaysia & Cross-sectional & $\begin{array}{l}498 \text { school } \\
\text { children aged } \\
6-12 \text { years old }\end{array}$ & Intestinal parasitic infections & $\begin{array}{l}\text { Access to piped } \\
\text { water, handwashing, } \\
\text { and sanitation. }\end{array}$ & $\begin{array}{l}\text { Considered the } \\
\text { effect of sex. }\end{array}$ & No & $\begin{array}{l}48.8 \% \text { of children had access to } \\
\text { piped water, } 46.4 \% \text { possessed an } \\
\text { in-house toilet. Unsafe water and the } \\
\text { absence of a toilet increased the risk } \\
\text { of infection by } 2 \text {-fold. Not washing } \\
\text { hands before eating, not cutting nails, } \\
\text { and not wearing shoes increased the } \\
\text { risk of infection by } 1.5 \text {-fold, while not } \\
\text { washing fruits and vegetables } \\
\text { increased the risk of infection by } \\
2.5 \text {-fold. Sex had no effect. }\end{array}$ \\
\hline Alemu et al. (2017) & Ethiopia & Cross-sectional & $\begin{array}{l}3,108 \text { children, } \\
\text { aged 6-59 } \\
\text { months old. }\end{array}$ & Child stunting & $\begin{array}{l}\text { Household level of } \\
\text { water treatment; } \\
\text { latrine usage }\end{array}$ & $\begin{array}{l}\text { Considered the } \\
\text { effect of gender }\end{array}$ & No & $\begin{array}{l}\text { Household level of water treatment } \\
\text { improved child height }(p<0.05) .23 \% \\
\text { of households used latrines which } \\
\text { reduced stunting (OR: } 0.39) \text {. Stunting } \\
\text { prevalence differed between boys } \\
(41.7 \%) \text { and girls ( } 37 \%) \text {, and being } \\
\text { female improved the child's height. }\end{array}$ \\
\hline Aluko et al. (2018) & Nigeria & & 312 individuals & $\mathrm{N} / \mathrm{A}$ & $\begin{array}{l}\text { Knowledge of } \\
\text { hygiene and } \\
\text { sanitation practices }\end{array}$ & $\begin{array}{l}\text { Assessed gender } \\
\text { differences. }\end{array}$ & No & $\begin{array}{l}\text { Reported knowledge on shared } \\
\text { household sanitation practices were } \\
\text { good }(66.3 \% \text { correct answers); } \\
\text { however, } 60.3 \% \text { of shared sanitation } \\
\text { facilities were dirty. } 62.8 \% \text { of } \\
\text { respondents had access to a toilet. }\end{array}$ \\
\hline Angoua et al. (2018) & $\begin{array}{l}\text { Côte } \\
\text { d'Ivoire }\end{array}$ & Cross-sectional & 556 households & No & $\begin{array}{l}\text { Access to clean } \\
\text { water, and improved } \\
\text { sanitation }\end{array}$ & $\begin{array}{l}\text { The presence of } \\
\text { women in the } \\
\text { household was a } \\
\text { considered factor. }\end{array}$ & No & $\begin{array}{l}\text { Nearly } 1 \text { in } 4 \text { households lacked } \\
\text { access to clean water, } 57 \% \text { lacked } \\
\text { improved sanitation. Having the head } \\
\text { of the household's wife in the home } \\
\text { improved access to clean water by } \\
\text { 3-fold. }\end{array}$ \\
\hline Atalabi et al. (2016) & Nigeria & Cross-sectional & 718 students & $\begin{array}{l}\text { Prevalence of genito-urinary } \\
\text { schistosomiasis }\end{array}$ & $\begin{array}{l}\text { Access to an } \\
\text { improved water } \\
\text { source }\end{array}$ & $\begin{array}{l}\text { Considered gender } \\
\text { differences and } \\
\text { maternal factors. }\end{array}$ & No & $\begin{array}{l}22.7 \% \text { of students possessed } \\
\text { genito-urinal schistosomiasis. Boys } \\
\text { were } 7 \text {-fold more likely to be infected } \\
\text { with schistosomiasis. Unclean water } \\
\text { was associated with increased } \\
\text { infections, as were mothers who were } \\
\text { employed as "brown collared } \\
\text { workers" or were homemakers. }\end{array}$ \\
\hline
\end{tabular}


TABLE 1 | Continued

\begin{tabular}{|c|c|c|c|c|c|c|c|c|}
\hline References & Country & Study design & Sample size & Health component & WASH outcome & Gender outcome & $\begin{array}{l}\text { Sex } \\
\text { disaggregated }\end{array}$ & Conclusion \\
\hline Baker et al. (2018) & Togo & Cross-sectional & $\begin{array}{l}16,473 \text { children in } \\
2009,16,890 \text { in } \\
2016\end{array}$ & $\begin{array}{l}\text { Prevalence of hookworm } \\
\text { infection }\end{array}$ & $\begin{array}{l}\text { Access to an } \\
\text { improved water } \\
\text { source, improved } \\
\text { sanitation, and } \\
\text { handwashing } \\
\text { stations. }\end{array}$ & $\begin{array}{l}\text { Compared gender } \\
\text { differences. }\end{array}$ & No & $\begin{array}{l}1 \text { in } 2 \text { children had access to } \\
\text { improved water, } 3 \text { in } 10 \text { had access } \\
\text { to a latrine. Prevalence of hookworm } \\
\text { decreased from } 32.4 \% \text { in } 2009 \text { to } \\
11.1 \% \text { in } 2015 \text { across all schools. } \\
\text { Unimproved drinking water sources } \\
\text { increased the odds of hookworm } \\
\text { infection by } 1.4-\text { fold. Access to an } \\
\text { improved drinking water off school } \\
\text { grounds, and handwashing stations } \\
\text { further reduced hookworm eggs in } \\
\text { stool by } 20 \% \text { each. Boys had nearly } \\
\text { twice as many hookworm eggs in } \\
\text { their stool than girls in both } 2009 \text { and } \\
2015 .\end{array}$ \\
\hline $\begin{array}{l}\text { Bisung and Elliott } \\
\text { (2018) }\end{array}$ & Kenya & Cross-sectional & 557 households & N/A & $\begin{array}{l}\text { Access to an } \\
\text { improved water } \\
\text { source }\end{array}$ & $\begin{array}{l}\text { Assessed } \\
\text { differences between } \\
\text { male and female } \\
\text { headed households. }\end{array}$ & No & $\begin{array}{l}72 \% \text { accessed piped water outside } \\
\text { their household premises. Round trips } \\
\text { for collecting water took, on average, } \\
7 \text { min. Female headed households } \\
\text { experienced less water security than } \\
\text { male headed households. }\end{array}$ \\
\hline Bornman et al. (2012) & South Africa & Cross-sectional & $\begin{array}{l}156 \text { female } \\
\text { caregivers }\end{array}$ & Concern of malaria & $\begin{array}{l}\text { Access to clean } \\
\text { water }\end{array}$ & Focused on women. & No & $\begin{array}{l}\text { Women were the primary collectors of } \\
\text { water. Between } 8 \text { and } 23 \% \text { of women } \\
\text { cited a lack of clean water as a daily } \\
\text { concern. Between } 86 \text { and } 93 \% \text { of } \\
\text { women attributed malaria to } \\
\text { mosquitos, and the remainder of } \\
\text { women associated malaria with dirty, } \\
\text { stagnant water. }\end{array}$ \\
\hline $\begin{array}{l}\text { Braxton and Larson } \\
\text { (2019) }\end{array}$ & Guatemala & Cross-sectional & $\begin{array}{l}10 \text { Mayan } \\
\text { caregivers }\end{array}$ & Conception of health & $\begin{array}{l}\text { Access to clean } \\
\text { water }\end{array}$ & $\begin{array}{l}\text { Mostly women were } \\
\text { interviewed. }\end{array}$ & No & $\begin{array}{l}\text { Access to clean drinking water was } \\
\text { universally linked to the concept of } \\
\text { good health }\end{array}$ \\
\hline Budhathoki et al. (2018) & Nepal & Cross-sectional & $\begin{array}{l}117 \text { women and } \\
\text { adolescent girls }\end{array}$ & $\mathrm{N} / \mathrm{a}$ & $\begin{array}{l}\text { Access to MHM and } \\
\text { hygiene resources; } \\
\text { private safe } \\
\text { locations }\end{array}$ & $\begin{array}{l}\text { Focused on } \\
\text { women's needs } \\
\text { following an } \\
\text { earthquake. }\end{array}$ & No & $\begin{array}{l}\text { Half of women and girls received } \\
\text { soap. } 1 \text { in } 5 \text { women listed MHM as a } \\
\text { need. No women received any } \\
\text { menstrual hygiene adsorbents in the } \\
\text { distributed relief materials within the } \\
1 \text { st month following the disaster. } \\
\text { Three-quarters of respondents used } \\
\text { reusable cloths for managing } \\
\text { menstrual bleeding. Less than half } \\
\text { reported the availability of private, } \\
\text { safe locations for attending to MHM } \\
\text { needs. }\end{array}$ \\
\hline
\end{tabular}


TABLE 1 | Continued

\begin{tabular}{|c|c|c|c|c|c|c|c|c|}
\hline References & Country & Study design & Sample size & Health component & WASH outcome & Gender outcome & $\begin{array}{l}\text { Sex } \\
\text { disaggregated }\end{array}$ & Conclusion \\
\hline Davis et al. (2018) & Indonesia & Cross-sectional & $\begin{array}{l}1,159 \text { adolescent } \\
\text { girls }\end{array}$ & No & $\begin{array}{l}\text { Access to } \mathrm{MHM} \text { and } \\
\text { hygiene resources }\end{array}$ & $\begin{array}{l}\text { Focused on } \\
\text { adolescent school } \\
\text { girls. }\end{array}$ & No & $\begin{array}{l}<10 \% \text { of girls used reusable cloths } \\
\text { and over half changed cloths at least } \\
\text { every } 4-8 \text { days. } 95 \% \text { washed their } \\
\text { genitals daily. In total, over } 60 \% \text { of } \\
\text { girls reported poor MHM practices. }\end{array}$ \\
\hline Dendup et al. (2018) & Bhutan & Cross-sectional & $\begin{array}{l}39,789 \\
\text { individuals from } \\
13,256 \\
\text { households }\end{array}$ & Under-five mortality & $\begin{array}{l}\text { Access to a safe } \\
\text { drinking water } \\
\text { source water, } \\
\text { sanitation facilities }\end{array}$ & $\begin{array}{l}\text { Considered } \\
\text { maternal and gender } \\
\text { indicators. }\end{array}$ & No & $\begin{array}{l}\text { A lack of safe sanitation facilities } \\
\text { increased the odds of under-five } \\
\text { mortality by } 1.5 \text {-fold, and access to } \\
\text { safe water had no effect. Among } \\
\text { gender-related factors, mothers who } \\
\text { were older than } 25 \text { reduced the risk of } \\
\text { under-five mortality by } 2-5 \text {-fold. Other } \\
\text { gender related factors had no effect. }\end{array}$ \\
\hline Desalegn et al. (2018) & Ethiopia & Cross-sectional & $\begin{array}{l}572 \text { lactating } \\
\text { mothers fasting } \\
\text { during lent, } 522 \\
\text { non-fasting } \\
\text { lactating mothers }\end{array}$ & $\begin{array}{l}\text { Frequency of underweight } \\
\text { mothers }\end{array}$ & $\begin{array}{l}\text { Access to an } \\
\text { improved water } \\
\text { source, and a } \\
\text { household toilet. }\end{array}$ & $\begin{array}{l}\text { Focused on } \\
\text { lactating mothers. }\end{array}$ & No & $\begin{array}{l}\text { Fasting mothers without a } \\
\text { non-improved water source, or a } \\
\text { toilet were } 1.6 \text {-fold, and } 1.5 \text {-fold, } \\
\text { respectively more likely to be } \\
\text { underweight. }\end{array}$ \\
\hline Doherty et al. (2007) & South Africa & $\begin{array}{l}\text { Prospective } \\
\text { cohort }\end{array}$ & 635 mothers & HIV-free status of infants & $\begin{array}{l}\text { Access to piped } \\
\text { water }\end{array}$ & $\begin{array}{l}\text { Focused on } \\
\text { maternal factors. }\end{array}$ & No & $\begin{array}{l}\text { Piped water was one of three criteria } \\
\text { necessary for appropriate formula } \\
\text { use. Women who used formula } \\
\text { without the appropriate conditions, or } \\
\text { who breast-fed their children had a } \\
\text { 3-fold increased risk of infant HIV } \\
\text { transmission. }\end{array}$ \\
\hline Donohue et al. (2017) & Kenya & Cross-sectional & $\begin{array}{l}1,704 \text { school } \\
\text { children }\end{array}$ & Prevalence of schistosomiasis & $\begin{array}{l}\text { Access to clean } \\
\text { water, sanitation; } \\
\text { exposure to } \\
\text { open-water sources }\end{array}$ & $\begin{array}{l}\text { Compared gender } \\
\text { differences. }\end{array}$ & No & $\begin{array}{l}\text { A lack of latrines and safe drinking } \\
\text { water increased self-reported } \\
\text { schistosomiasis by } 2.5 \text { and } 3 \text {-fold, } \\
\text { respectively. Frequent visits to the } \\
\text { river ( }>1+\text { per day) reduced risk. } \\
\text { Boys were } 2.5 \text {-fold more likely to } \\
\text { self-report schistosomiasis. }\end{array}$ \\
\hline Fuge et al. (2015) & Ethiopia & Cross-sectional & $\begin{array}{l}398 \text { Pregnant } \\
\text { women/ mothers }\end{array}$ & $\begin{array}{l}\text { Malaria transmission and } \\
\text { infection }\end{array}$ & $\begin{array}{l}\text { knowledge of } \\
\text { sanitation and } \\
\text { hygiene practices }\end{array}$ & $\begin{array}{l}\text { Pregnant women } \\
\text { were the focused } \\
\text { population. }\end{array}$ & No & $\begin{array}{l}261 \text { women }(66 \%) \text { responded that } \\
\text { malaria was transmitted due to poor } \\
\text { personal hygiene and environmental } \\
\text { sanitation. }\end{array}$ \\
\hline Gaspar et al. (2017) & South Africa & Cross-sectional & 751 mothers & $\begin{array}{l}\text { Serum concentration of the } \\
\text { anti-malaria chemicals } \\
\text { dichlorodiphenyltichlorethane } \\
\text { (DDT) and } \\
\text { dichlorodiphenyldichloroethylene } \\
\text { (DDE) }\end{array}$ & $\begin{array}{l}\text { Access to an } \\
\text { improved water } \\
\text { source; frequency of } \\
\text { washing the } \\
\text { household }\end{array}$ & $\begin{array}{l}\text { Focused on } \\
\text { pregnant women. }\end{array}$ & No & $\begin{array}{l}\text { Living further from an open body of } \\
\text { water, having in-house piped water, } \\
\text { and mopping the house } 7 \text {-times } \\
\text { weekly decreased DDT exposure. }\end{array}$ \\
\hline
\end{tabular}


TABLE 1 | Continued

References

Country Study design Sample size

Health component

WASH outcome

Gender outcome

Sex

disaggregated

Geere et al. (2018) South

Cross-sectional 3, 365 adults and Self-reported pain

Africa,

children

Method and

frequency of

carrying water

Focused on

No

Ghana and
Vietnam

Guy et al. (2018)

Benin

Cross-sectional 65 women

Presence of heavy metals in the Type of primary

and girls.

and girls.

Focused on

No

women.

pregnant women.

No

Hall and Le (2018)

Vietnam

Cross-sectional 600 small scale

farms

Implementation of waterbourne
disease mitigation strategies

Type of primary

Assessed gender

differences in

decision-making.

Assessed gender

differences in how

information was

shared in the

community

access.
Conclusion

Carrying water increased pain in the

upper back by 2 -fold and in the

hands by 3 -fold compared to those who never carried water.

Compared with running water,

women who received water from a

drill-pump possessed higher levels of

lead in their blood during the first

trimester.

Rain water or a drilled well as the primary water source increased the odds of engaging in mitigation by 1.5 and 2-fold, respectively. Female healthcare decision makers increased the odds of mitigation by 1.5 -fold.

In adjusted analyses, across Nepal, Pakistan, and Bangladesh, a mother's incomplete secondary or primary education increased the odds of contracting diarrhea by 1.2-1.7-fold. The water source or level of sanitation had little impact on the incidence of morbidity in children.

$42 \%$ of adults reported a lack of water sources, and $79 \%$ reported water was too far away. Households possessed a lack of clean water nearly half of the time. The average time to retrieve water was 54 min. Participants of the same sex were 2.2 times more likely to share information on water access.

Female heads/partners ( 40\%) and daughters ( 20\%) were the primary water carriers. Regardless of the time it took for water fetching, improving water access was prioritized more than improving employment opportunities. Male headed households, and sons traveling $>15$ min to fetch water were $>10$-fold more likely to state water access as a more important priority than health services. Girls who traveled $<15 \mathrm{~min}$ were 8.5 -fold more likely to declare employment as an important priority than water access. 
TABLE 1 | Continued

\begin{tabular}{|c|c|c|c|c|c|c|c|c|}
\hline References & Country & Study design & Sample size & Health component & WASH outcome & Gender outcome & $\begin{array}{l}\text { Sex } \\
\text { disaggregated }\end{array}$ & Conclusion \\
\hline Inobaya et al. (2018) & $\begin{array}{l}\text { The } \\
\text { Philippines }\end{array}$ & Cross-sectional & $\begin{array}{l}2,189 \text { adults, } \\
>18 \text { years old }\end{array}$ & Compliance to drug regimen & $\begin{array}{l}\text { Knowledge of water } \\
\text { and sanitation } \\
\text { practices }\end{array}$ & $\begin{array}{l}\text { Assessed gender } \\
\text { differences }\end{array}$ & No & $\begin{array}{l}\text { Those who believed that open } \\
\text { defecation and poor sanitation were } \\
\text { mechanisms of infection and those } \\
\text { who believed that avoiding dirty } \\
\text { drinking water could prevent } \\
\text { schistosomiasis were } 1.4 \text {-fold and } \\
2.1 \text {-fold more likely to not comply } \\
\text { with schistosomiasis chemotherapy. } \\
\text { However, those who believed } \\
\text { schistosomiasis could be transmitted } \\
\text { by dirty water, and were over } 30 \text { years } \\
\text { old, were } 3-5 \text {-fold more likely to be } \\
\text { compliant. Women were } 1.7 \text {-fold } \\
\text { more likely to not comply with } \\
\text { treatment. }\end{array}$ \\
\hline $\begin{array}{l}\text { Kapito-Tembo et al. } \\
\text { (2009) }\end{array}$ & Malawi & Cross-sectional & 1,150 students & Prevalence of schistosomiasis & $\begin{array}{l}\text { Proximity to open } \\
\text { water }\end{array}$ & $\begin{array}{l}\text { Assessed gender } \\
\text { differences. }\end{array}$ & No & $\begin{array}{l}\text { Schistosomiasis eggs were detected } \\
\text { in } 10 \% \text { of students. Male students } \\
\text { were at a } 1.8 \text {-fold increased risk of } \\
\text { schistosomiasis eggs. Knowledge of } \\
\text { an open water source and having an } \\
\text { open-water source within } 1 \mathrm{~km} \text { of the } \\
\text { school increased the risk of infection } \\
\text { by } 1.9 \text {-fold and } 5.4 \text {-fold, respectively. }\end{array}$ \\
\hline Khan et al. (2017) & Belize & Cross-sectional & $\begin{array}{l}429 \text { households, } \\
267 \text { women aged } \\
15-49 \text { years old. }\end{array}$ & N/A & $\begin{array}{l}\text { Access to clean } \\
\text { water, improved } \\
\text { sanitation, and MHM } \\
\text { resources. }\end{array}$ & $\begin{array}{l}\text { Considered the } \\
\text { needs of women. }\end{array}$ & No & $\begin{array}{l}\text { Nearly } 9 \text { in } 10 \text { had water available } \\
\text { when needed and } 2 / 3 \text { had water free } \\
\text { from E. coli. A majority of pit latrines } \\
\text { and septic tanks had never been } \\
\text { emptied. } 95 \% \text { of women had a } \\
\text { private place to wash and } 98 \% \text { had } \\
\text { access to materials for managing } \\
\text { their period. }\end{array}$ \\
\hline Kwiringira et al. (2014) & Uganda & Cross-sectional & $\begin{array}{l}18 \text { focus group } \\
\text { discussions, and } \\
16 \text { informant } \\
\text { interviews }\end{array}$ & N/A & Access to sanitation & $\begin{array}{l}\text { Focused on } \\
\text { outcomes in women } \\
\text { and girls. }\end{array}$ & No & $\begin{array}{l}\text { Women, children, and the elderly } \\
\text { complained that latrines were not } \\
\text { conveniently located, not clean, and } \\
\text { not safe to use at night. Difficulties } \\
\text { with keeping latrines clean due to } \\
\text { communal use. Unclean latrines were } \\
\text { abandoned. }\end{array}$ \\
\hline
\end{tabular}

(Continued) 
TABLE 1 | Continued

\begin{tabular}{|c|c|c|c|c|c|c|c|c|}
\hline References & Country & Study design & Sample size & Health component & WASH outcome & Gender outcome & $\begin{array}{l}\text { Sex } \\
\text { disaggregated }\end{array}$ & Conclusion \\
\hline Lubon et al. (2018) & Nepal & Cross-sectional & $\begin{array}{l}16 \text { interviews, } \\
\text { three focus group } \\
\text { discussions with } \\
23 \text { participants }\end{array}$ & No & $\begin{array}{l}\text { perceptions of oral } \\
\text { hygiene; frequency } \\
\text { of oral hygiene } \\
\text { utilization }\end{array}$ & $\begin{array}{l}\text { Focused on cultural } \\
\text { practices in } \\
\text { pregnant women. }\end{array}$ & No & $\begin{array}{l}\text { Women agreed that oral hygiene was } \\
\text { important to prevent disease but had } \\
\text { mixed views on the association } \\
\text { between oral hygiene during } \\
\text { pregnancy and healthy birth } \\
\text { outcomes. Madhesi participants } \\
\text { cleaned their teeth once a day using } \\
\text { either a toothbrush and toothpaste or } \\
\text { a teeth cleaning twig. Norms in the } \\
\text { Pahadi women included brushing } \\
\text { their teeth twice a day or more. A } \\
\text { pertinent barrier was the } \\
\text { inaccessibility of toothbrushes and } \\
\text { toothpaste. }\end{array}$ \\
\hline $\begin{array}{l}\text { Magnusson and } \\
\text { Bickenbach (2018) }\end{array}$ & $\begin{array}{l}\text { Sierra } \\
\text { Leone }\end{array}$ & Cross-sectional & $\begin{array}{l}139 \text { lower-limb } \\
\text { prosthetics } \\
\text { patients }\end{array}$ & $\begin{array}{l}\text { Access to healthcare services, } \\
\text { and holistic measures of health. }\end{array}$ & $\begin{array}{l}\text { Access to clean } \\
\text { water }\end{array}$ & $\begin{array}{l}\text { Compared gender } \\
\text { differences. }\end{array}$ & No & $\begin{array}{l}\text { Half of participants with prothestics } \\
\text { lacked access to clean water. Those } \\
\text { in rural settings had significantly less } \\
\text { access. Gender had an inconsistent } \\
\text { effect on health-related measures. }\end{array}$ \\
\hline Marinda et al. (2018) & Namibia & Cross-sectional & $\begin{array}{l}714 \text { mother-child } \\
\text { dyads; children } \\
\text { aged 6-59 } \\
\text { months old }\end{array}$ & $\begin{array}{l}\text { Stunting in children aged 6-23 } \\
\text { and } 24-59 \text { months. }\end{array}$ & $\begin{array}{l}\text { Access to treated } \\
\text { water }\end{array}$ & $\begin{array}{l}\text { Considered maternal } \\
\text { characteristics, and } \\
\text { sex of the child. }\end{array}$ & No & $\begin{array}{l}\text { Access to treated water reduced the } \\
\text { risk of stunting by } 2 \text {-fold. A mother's } \\
\text { BMl increased the risk of stunting in } \\
\text { infants } 6-23 \text { months old. The child's } \\
\text { sex had no impact. }\end{array}$ \\
\hline Nasr et al. (2013) & Malaysia & Cross-sectional & $\begin{array}{l}215 \text { households, } \\
\text { and } 484 \text { children }\end{array}$ & $\begin{array}{l}\text { Soil-transmitted helminth } \\
\text { infection; diarrhea. }\end{array}$ & $\begin{array}{l}\text { Access to clean } \\
\text { water, and frequency } \\
\text { of handwashing }\end{array}$ & $\begin{array}{l}\text { Assessed gender } \\
\text { differences. }\end{array}$ & Yes & $\begin{array}{l}54.8 \% \text { of respondents did not wash } \\
\text { their hands before meals and } 37.7 \% \\
\text { did not after defecation. Children who } \\
\text { washed their hands before eating and } \\
\text { after defecation experienced reduced } \\
\text { rates of infection; hand washing } \\
\text { before eating was higher in males } \\
\text { ( } 53.3 \text { vs. } 39.2 \% \text { females) and also } \\
\text { after defecation ( } 71.1 \text { vs. } 56.0 \% \text { ). }\end{array}$ \\
\hline Njuguna (2019) & Kenya & $\begin{array}{l}\text { Retrospective } \\
\text { longitudinal }\end{array}$ & $\begin{array}{l}\text { 2014: } N=40 \\
\text { 300; } 2008: N= \\
9,936,2004: N= \\
8,561 \\
\text { households }\end{array}$ & N/A & $\begin{array}{l}\text { Access to improved } \\
\text { sanitation }\end{array}$ & $\begin{array}{l}\text { Compared gender } \\
\text { differences. }\end{array}$ & No & $\begin{array}{l}\text { Open defecation was reduced from } \\
16.2 \% \text { in } 2003 \text { to } 9.9 \% \text { in } 2014 \text {. Pit } \\
\text { latrines without a slab were most } \\
\text { commonly used ( } 37.9 \% \text { in } 2014 \text { ). The } \\
\text { gender of the household head } \\
\text { predicted open defecation in } 2003 \\
\text { and } 2008, \text { but not in } 2014 . \text { It was not } \\
\text { clear from the study which gender } \\
\text { predicted open defecation. }\end{array}$ \\
\hline
\end{tabular}


TABLE 1 | Continued

\begin{tabular}{|c|c|c|c|c|c|c|c|c|}
\hline References & Country & Study design & Sample size & Health component & WASH outcome & Gender outcome & $\begin{array}{l}\text { Sex } \\
\text { disaggregated }\end{array}$ & Conclusion \\
\hline Oberoi et al. (2014) & India & Cross-sectional & 250 patients & $\begin{array}{l}\text { Perceptions of oral health on } \\
\text { overall health }\end{array}$ & $\begin{array}{l}\text { Frequency of oral } \\
\text { hygiene utilization }\end{array}$ & $\begin{array}{l}\text { Assessed gender } \\
\text { differences }\end{array}$ & Yes & $\begin{array}{l}\text { Eight in } 10 \text { used a toothbrush and } \\
\text { toothpaste to clean their teeth, over } \\
\text { half brushed their teeth once daily. } \\
\text { Although not statistically significant, } \\
64.1 \% \text { of males found that oral } \\
\text { hygiene was essential to their overall } \\
\text { health compared to } 56 \% \text { of females. } \\
\text { Twice as many more women cited } \\
\text { cost as a barrier to oral hygiene. } \\
\text { Women changed their toothbrush } \\
\text { more infrequently. }\end{array}$ \\
\hline $\begin{array}{l}\text { Odetola and Fakorede } \\
\text { (2018) }\end{array}$ & Nigeria & Cross-sectional & 66 women & Satisfaction with perinatal care & $\begin{array}{l}\text { Access to clean } \\
\text { water }\end{array}$ & $\begin{array}{l}\text { Attitudes of } \\
\text { postpartum women. }\end{array}$ & No & $\begin{array}{l}80.3 \% \text { of women felt that the hospital } \\
\text { had adequate water and electricity. } \\
\text { Inadequate water contributed to } \\
\text { dissatisfaction. }\end{array}$ \\
\hline $\begin{array}{l}\text { O'Reilly and Louis } \\
\text { (2014) }\end{array}$ & India & Mixed methods & 607 households & N/A & $\begin{array}{l}\text { Access to improved } \\
\text { sanitation. }\end{array}$ & $\begin{array}{l}\text { Assessed gender } \\
\text { differences. }\end{array}$ & No & $\begin{array}{l}\text { Shaming, fines, and withholding } \\
\text { benefits were effective in getting } \\
\text { households to build and use latrines. } \\
\text { Women reported needing privacy to } \\
\text { defecate, while men were less } \\
\text { concerned. }\end{array}$ \\
\hline Prado et al. (2019) & $\begin{array}{l}\text { Ghana, } \\
\text { Malawi, } \\
\text { Burkina } \\
\text { Faso }\end{array}$ & $\begin{array}{l}\text { Prospective } \\
\text { cohort }\end{array}$ & $\begin{array}{l}\text { 18-month-old } \\
\text { children from } \\
\text { Ghana }(N= \\
1,039) \text {, Malawi }(N \\
=684 \text { and } 1,504) \\
\text { and Burkina Faso } \\
(N=2,619)\end{array}$ & Infant stunting & $\begin{array}{l}\text { Access to improved } \\
\text { water }\end{array}$ & $\begin{array}{l}\text { Considered } \\
\text { maternal factors. }\end{array}$ & No & $\begin{array}{l}\text { Improved household water, maternal } \\
\text { education, maternal BMI, maternal } \\
\text { height, and maternal hemoglobin } \\
\text { levels were associated with reduced } \\
\text { stunting. }\end{array}$ \\
\hline Sato et al. (2016) & $\begin{array}{l}\text { The } \\
\text { Philippines }\end{array}$ & Cross-sectional & 53 women & $\begin{array}{l}\text { Assessed health needs, and } \\
\text { presence of diarrhea following a } \\
\text { typhoon. }\end{array}$ & $\begin{array}{l}\text { Access to clean } \\
\text { water and sanitation }\end{array}$ & $\begin{array}{l}\text { Focused on } \\
\text { pregnant women. }\end{array}$ & No & $\begin{array}{l}\text { Pregnant women complained of } \\
\text { diarrhea and leptospirosis due to the } \\
\text { storm surge and unsanitary } \\
\text { conditions. Women experienced } \\
\text { abnormal pregnancy symptoms, and } \\
\text { stress disorders. }\end{array}$ \\
\hline Scott et al. (2018) & Zambia & Cross-sectional & $\begin{array}{l}167 \text { women who } \\
\text { were pregnant or } \\
\text { with a child under } \\
2 \text { years old; } 17 \\
\text { focus group } \\
\text { discussions with } \\
135 \text { participants }\end{array}$ & N/A & $\begin{array}{l}\text { Access to clean } \\
\text { water }\end{array}$ & $\begin{array}{l}\text { Pregnant women } \\
\text { and new mothers } \\
\text { were surveyed, } \\
\text { focus group } \\
\text { discussion answers } \\
\text { between men and } \\
\text { women were } \\
\text { compared }\end{array}$ & Yes & $\begin{array}{l}\text { There was limited access to water } \\
\text { within maternity waiting homes. } \\
\text { Respondents deemed it was } \\
\text { culturally inappropriate to house } \\
\text { pregnant women in waiting homes } \\
\text { alongside families, travelers, or newly } \\
\text { delivered mothers. Due to a lack of } \\
\text { lighting and lockboxes, security was } \\
\text { also a concern. }\end{array}$ \\
\hline
\end{tabular}




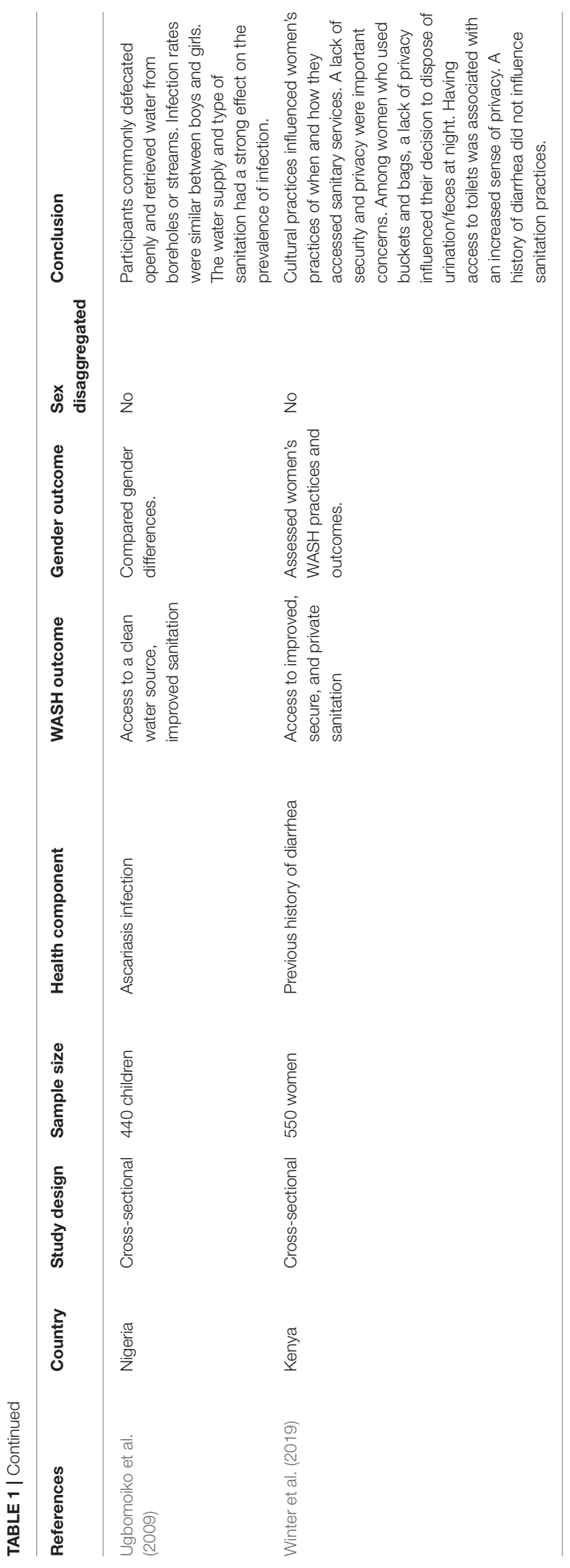

included a lack of privacy, conveniently located latrines, as well as locks and security (Kwiringira et al., 2014; O'Reilly and Louis, 2014; Winter et al., 2019). In particular, a lack of privacy and security were related to women emptying bags and buckets at night, a behavior that can often increase the exposure of women to the threat of violence or sexual assault (Winter et al., 2019).

Generally, studies that compared access to sanitation between men and women found largely unremarkable gender differences (Ugbomoiko et al., 2009; Al-Delaimy et al., 2014; Alemu et al., 2017; Baker et al., 2018). However, one study in rural Ethiopia found that male-headed households were $\sim 4$-fold more likely to use household latrines than female-headed families (Aiemjoy et al., 2017). In addition, Njuguna (2019) showed that in Kenya, in 2004 and 2008, but not 2014, female-headed households were more likely to openly defecate than male-headed households. There is further evidence that girls had reduced access to improved hygienic practices. Nasr et al. (2013) comment that boys hand washed more frequently than girls, and Oberoi et al. demonstrated that girls less often changed their toothbrush and cited cost as a barrier (Oberoi et al., 2014).

A small fraction (6\%) of studies focused on the role of MHM, where women reported a lack of proper MHM products, such as clean pads, in addition to private areas and an absence of water provisioning for cleaning and sanitation needs (Khan et al., 2017; Budhathoki et al., 2018; Davis et al., 2018). Davis et al. (2018) demonstrated how one in 10 students missed school due to menstruation, and this could, in part be attributed to menstrual stigma. However, the link between WASH resources in school and absenteeism was not definitive.

\section{Poor Access to WASH Resources Disproportionately Impacts Health Burdens Among Women and Girls, and Particularly Children}

We found significant evidence of gender intersecting with WASH and health, with 33 of the 46 observational studies (72\%) assessing a health component in relation to WASH (Figure 2). In total, 16 (48\%) studies assessed childhood health and childhood infectious diseases, mainly centering on under-five mortality (15\%), schistosomiasis/intestinal parasites (18\%), and childstunting (12\%). Concretely, studies showed that maternal, or household access to clean water significantly reduced the risk of under-five mortality (Ahmed et al., 2016; Acheampong et al., 2017, 2018), child stunting (Akombi et al., 2017; Vos et al., 2017; Marinda et al., 2018), schistosomiasis (Atalabi et al., 2016; Donohue et al., 2017), and hookworm infections (Baker et al., 2018). Household piped water was one of the three stability factors needed to reduce HIV transmission for newborn infants (Doherty et al., 2007). Outside of the home, exposure to open water near schools increases the risk of schistosomiasis (Kapito-Tembo et al., 2009). Other aspects of WASH, including improved sanitation and handwashing, likewise reduced underfive mortality (Ahmed et al., 2016; Dendup et al., 2018), and schistosomiasis (Donohue et al., 2017), or acquiring other soiltransmitted helminths and parasites (Baker et al., 2018). In addition to the availability of sustainable WASH resources, maternal factors contributed to health burdens. Demographic 
TABLE 2 | Intervention studies included in the analysis assessed for their WASH outcome, gender outcome, and inclusion of a health component.

\begin{tabular}{|c|c|c|c|c|c|c|c|c|c|}
\hline References & Country & Study design & Sample size & $\begin{array}{l}\text { Health } \\
\text { component }\end{array}$ & WASH intervention & WASH outcome & Gender outcome & $\begin{array}{l}\text { Sex } \\
\text { disaggregated }\end{array}$ & Conclusion \\
\hline Alzaher et al. (2018) & Saudi Arabia & $\begin{array}{l}\text { Cluster randomized } \\
\text { control trial }\end{array}$ & $\begin{array}{l}616 \text { primary girl } \\
\text { students }\end{array}$ & $\begin{array}{l}\text { Considered schoo } \\
\text { absences due to } \\
\text { upper-respiratory } \\
\text { tract infections. }\end{array}$ & $\begin{array}{l}\text { 1-h Arabic handwashing } \\
\text { workshop. }\end{array}$ & Effect of handwashing & $\begin{array}{l}\text { Focused on } \\
\text { schoolgirls }\end{array}$ & is & $\begin{array}{l}\text { School absence due to } \\
\text { infection was lower in the } \\
\text { two intervention } \\
\text { implemented schools ( } 0.54 \\
\text { and } 1.02 \text { cases per } 100 \\
\text { school girls/day) than in the } \\
\text { two control group schools } \\
(0.24 \text { and } 0.51 \text { cases per } \\
100 \text { school girls/day). } \\
\text { Statistics are not reported. }\end{array}$ \\
\hline $\begin{array}{l}\text { Cairncross et al. } \\
\text { (2005) }\end{array}$ & India & Prospective cohort & $\begin{array}{l}515 \text { women, } 345 \\
\text { households }\end{array}$ & $\mathrm{N} / \mathrm{A}$ & $\begin{array}{l}\text { Health awareness } \\
\text { campaign which } \\
\text { included education } \\
\text { classes to promote } \\
\text { awareness of } \\
\text { sustainable WASH } \\
\text { practices }\end{array}$ & $\begin{array}{l}\text { Frequency of } \\
\text { handwashing; hygiene } \\
\text { practices }\end{array}$ & $\begin{array}{l}\text { Considered sex } \\
\text { differences. }\end{array}$ & is & $\begin{array}{l}\text { Handwashing practices } \\
\text { were more significant than } \\
50 \% \text { in intervention } \\
\text { implemented areas, } \\
\text { compared with }<10 \% \text { in } \\
\text { control areas. Nearly } \\
\text { three-quarters of } \\
\text { households with women } \\
\text { remembered the education } \\
\text { campaign, which is in } \\
\text { contrast to only } 18.5 \% \text { of } \\
\text { households with only men. } \\
\text { The educational classes } \\
\text { were associated with a } \\
2 \text {-fold increase in } \\
\text { handwashing practices by } \\
\text { women. }\end{array}$ \\
\hline Chaudhuri (2017) & $\begin{array}{l}\text { France, } \\
\text { Roma }\end{array}$ & $\begin{array}{l}\text { Longitudinal Cross } \\
\text { Sectional }\end{array}$ & 30 women & $\begin{array}{l}\text { Illness, including } \\
\text { diarrhea, urinary } \\
\text { tract infections, } \\
\text { parasites, eye } \\
\text { infection. }\end{array}$ & $\begin{array}{l}\text { Community } \\
\text { engagement } \\
\text { intervention to design, } \\
\text { construct and maintain } \\
\text { toilets. }\end{array}$ & $\begin{array}{l}\text { Access to MHM } \\
\text { resources; access to } \\
\text { private safe latrines. }\end{array}$ & Sampled women & (1) & $\begin{array}{l}\text { After } 18 \text { months, the } \\
\text { number of women reporting } \\
\text { difficulties with their } \\
\text { menstrual health needs } \\
\text { dropped from } 92 \text { to } 53 \% \text {. } \\
\text { Reported incidence of } \\
\text { diarrhea reduced from } 30 \text { to } \\
6 \% .96 \text { and } 85 \% \text { of women } \\
\text { felt that privacy and safety } \\
\text { were issues, respectively, } \\
\text { and these frequencies } \\
\text { dropped to } 41 \text { and } 71 \% \\
\text { saying privacy and safety } \\
\text { were issues. }\end{array}$ \\
\hline
\end{tabular}


TABLE 2 | Continued

\begin{tabular}{|c|c|c|c|c|c|c|c|c|c|}
\hline References & Country & Study design & Sample size & $\begin{array}{l}\text { Health } \\
\text { component }\end{array}$ & WASH intervention & WASH outcome & Gender outcome & $\begin{array}{l}\text { Sex } \\
\text { disaggregated }\end{array}$ & Conclusion \\
\hline Huq et al. (2010) & $\begin{array}{l}\text { Matlab, } \\
\text { Bangladesh }\end{array}$ & Cohort study & $\begin{array}{l}7,233 \text { village women } \\
\text { collecting water daily }\end{array}$ & $\begin{array}{l}\text { Incidence of } \\
\text { cholera-related } \\
\text { hospital visitations }\end{array}$ & $\begin{array}{l}\text { A simple sari water } \\
\text { filtering method }\end{array}$ & Access to clean water & $\begin{array}{l}\text { Focused on women } \\
\text { fetching water. }\end{array}$ & nNo & $\begin{array}{l}31 \% \text { of the village women } \\
\text { continued to use the water } \\
\text { filter } 5 \text { years after the } \\
\text { intervention. The incidence } \\
\text { of cholera hospital } \\
\text { visitations was reduced by } \\
25 \% \text { in the filter group, } \\
\text { although this was not } \\
\text { significant. }\end{array}$ \\
\hline Katsivo et al. (1993) & Kenya & $\begin{array}{l}\text { Cross-sectional } \\
\text { study }\end{array}$ & 203 head of households & $\begin{array}{l}\text { Knowledge of } \\
\text { schistosomiasis } \\
\text { transmission }\end{array}$ & $\begin{array}{l}\text { Handpumps, shallow } \\
\text { wells, pit latrines were } \\
\text { installed at } 6 \text { well-sites. }\end{array}$ & $\begin{array}{l}\text { Access to clean water, } \\
\text { and sanitation }\end{array}$ & $\begin{array}{l}\text { Perceptions of the } \\
\text { male and female } \\
\text { head of households } \\
\text { were considered }\end{array}$ & ( & $\begin{array}{l}\text { Following the intervention, } \\
82 \% \text { head of households } \\
\text { believed their children } \\
\text { appeared healthier as a } \\
\text { result of the potable water } \\
\text { and bathrooms near the } \\
\text { well sites. Almost everyone } \\
(99 \%) \text { believed that the } \\
\text { intervention had controlled } \\
\text { schistosomiasis. More than } \\
90 \% \text { knew the cause of } \\
\text { schistosomiasis, how it is } \\
\text { transmitted, its treatment, } \\
\text { and how to prevent and } \\
\text { control it. }\end{array}$ \\
\hline Magnin et al. (2018) & Madagascar & Cross-sectional & 74 mothers & $\begin{array}{l}\text { Malnutrition and } \\
\text { broad child health } \\
\text { outcomes. }\end{array}$ & $\begin{array}{l}\text { 35-days educational } \\
\text { program on children's } \\
\text { nutrition, WASH, and } \\
\text { health. }\end{array}$ & $\begin{array}{l}\text { Level of hygiene } \\
\text { education; frequency of } \\
\text { handwashing; access to } \\
\text { clean water. }\end{array}$ & $\begin{array}{l}\text { The intervention } \\
\text { focused on } \\
\text { mothers of the } \\
\text { children. }\end{array}$ & No & $\begin{array}{l}\text { The WASH component of } \\
\text { the intervention was cited } \\
\text { by participants as being } \\
\text { successful and improved } \\
\text { the children's health. }\end{array}$ \\
\hline Nyoka et al. (2017) & $\begin{array}{l}\text { Northwest } \\
\text { Kenya, } \\
\text { (Kakuma } \\
\text { refugee } \\
\text { camp), }\end{array}$ & $\begin{array}{l}\text { Prospective } \\
\text { longitudinal study }\end{array}$ & $\begin{array}{l}\text { Post-implementation of } \\
\text { Dinka and Somali } \\
\text { Refugees with 6-10 } \\
\text { participants each. }\end{array}$ & $\mathrm{N} / \mathrm{A}$ & $\begin{array}{l}\text { Implementation of new } \\
\text { sanitation system }\end{array}$ & $\begin{array}{l}\text { Access to improved } \\
\text { sanitatation }\end{array}$ & $\begin{array}{l}\text { Specifically } \\
\text { considered } \\
\text { women's needs. }\end{array}$ & No & $\begin{array}{l}\text { For Dinka participants, } \\
\text { sanitation at the camp was } \\
\text { as an improvement. Using } \\
\text { latrines was better than } \\
\text { open defecation. Somali } \\
\text { participants did not prefer } \\
\text { latrines. Some women with } \\
\text { genital mutilation could not } \\
\text { use toilets easily }\end{array}$ \\
\hline
\end{tabular}

(Continued) 
TABLE 2 | Continued

\begin{tabular}{|c|c|c|c|c|c|c|c|c|c|}
\hline References & Country & Study design & Sample size & $\begin{array}{l}\text { Health } \\
\text { component }\end{array}$ & WASH intervention & WASH outcome & Gender outcome & $\begin{array}{l}\text { Sex } \\
\text { disaggregated }\end{array}$ & Conclusion \\
\hline $\begin{array}{l}\text { Pickering et al. } \\
\text { (2017) }\end{array}$ & $\begin{array}{l}\text { Bunoma, } \\
\text { Kakamega, } \\
\text { Vihiga, and } \\
\text { Busia, Kenya, } \\
\text { (rural } \\
\text { population, } \\
\text { pregnant } \\
\text { women) }\end{array}$ & Cross-sectional & $\begin{array}{l}499 \text { households at } 6 \\
\text { months, } 531 \\
\text { households at } 18 \\
\text { months, and } 7,691 \\
\text { household at } 24-36 \\
\text { months }\end{array}$ & $\mathrm{N} / \mathrm{A}$ & $\begin{array}{l}\text { A program distributed } 1 \\
\text { million water-filters. }\end{array}$ & $\begin{array}{l}\text { Access to improved } \\
\text { water sources }\end{array}$ & $\begin{array}{l}\text { Sampled } \\
\text { households with } \\
\text { pregnant women }\end{array}$ & , & $\begin{array}{l}\text { Microbial water quality was } \\
\text { improved in filtered stored } \\
\text { drinking water when } \\
\text { collected at 24-26 months } \\
\text { after filter distribution; } \\
\text { however, fecal indicator } \\
\text { bacteria Escherichia coli } \\
\text { remained present. 19\% of } \\
\text { households reported } \\
\text { retained filter usage after } \\
2-3 \text { years. }\end{array}$ \\
\hline Rose et al. (2006) & $\begin{array}{l}\text { Vellore, Tamil } \\
\text { Nadu. }\end{array}$ & $\begin{array}{l}\text { Prospective cohort } \\
\text { study }\end{array}$ & 200 children & $\begin{array}{l}\text { Incidence of } \\
\text { diarrhea }\end{array}$ & $\begin{array}{l}\text { Children were provided } \\
\text { with solar disinfected } \\
\text { water }\end{array}$ & Clean water & $\begin{array}{l}\text { Mothers were } \\
\text { interviewed for trial } \\
\text { design and } \\
\text { feasibility. }\end{array}$ & No & $\begin{array}{l}\text { Solar treated water reduced } \\
\text { the incidence of diarrhea by } \\
40 \% \text {. Mothers believed the } \\
\text { treatment to be feasible. }\end{array}$ \\
\hline West et al. (1996) & $\begin{array}{l}\text { Kongwa, } \\
\text { Tanzania }\end{array}$ & $\begin{array}{l}\text { A randomized, } \\
\text { longitudinal study }\end{array}$ & $\begin{array}{l}240 \text { households, a total } \\
\text { of } 1,168 \text { participants }\end{array}$ & $\begin{array}{l}\text { Risk of and } \\
\text { frequency of } \\
\text { severe trachoma }\end{array}$ & $\begin{array}{l}\text { Face-washing } \\
\text { intervention }\end{array}$ & $\begin{array}{l}\text { Access to a clean water, } \\
\text { and hygiene resources. }\end{array}$ & $\begin{array}{l}\text { Sex distribution of } \\
\text { children with } \\
\text { trachoma, and } \\
\text { prevalence of } \\
\text { episodes of severe } \\
\text { trachoma by sex, } \\
\text { and a risk factor for } \\
\text { severe trachoma. }\end{array}$ & Yes & $\begin{array}{l}\text { A two-fold increase in the } \\
\text { risk of constant, severe } \\
\text { trachoma in females vs. } \\
\text { males; children with a clean } \\
\text { face had a } 40 \% \text { decrease } \\
\text { risk of having severe } \\
\text { trachoma at } 1 \text { year } \\
\text { follow-up, children with } \\
\text { severe trachoma decreased } \\
\text { from } 31 \text { to } 11 \% \text { and at } \\
\text { every time point, females } \\
\text { had more sever trachoma. }\end{array}$ \\
\hline Williams et al. (2015) & Haiti & $\begin{array}{l}\text { Cross-sectional } \\
\text { study }\end{array}$ & $\begin{array}{l}17 \text { focus-group } \\
\text { discussions }\end{array}$ & $\begin{array}{l}\text { Frequency of } \\
\text { cholera and } \\
\text { diarrhea }\end{array}$ & $\begin{array}{l}\text { Health messages on } \\
\text { sustainable WASH } \\
\text { practices }\end{array}$ & $\begin{array}{l}\text { Access to clean water, } \\
\text { improved sanitation }\end{array}$ & $\begin{array}{l}\text { Considered } \\
\text { women's focus } \\
\text { group discussions }\end{array}$ & , & $\begin{array}{l}\text { Focused group discussions } \\
\text { revealed that both cholera } \\
\text { and diarrhea were } \\
\text { observed. Members } \\
\text { reported improved WASH } \\
\text { practices following the } \\
\text { messages, and diarrhea } \\
\text { was reportedly reduced. A } \\
\text { lack of latrines was the most } \\
\text { commonly cited need. } \\
\text { There was a marked gender } \\
\text { difference, generally, women } \\
\text { were more informed on } \\
\text { improved water and } \\
\text { sanitation practices. }\end{array}$ \\
\hline
\end{tabular}


TABLE 2 | Continued

\begin{tabular}{|c|c|c|c|c|c|c|c|c|}
\hline References & Study design & Sample size & $\begin{array}{l}\text { Health } \\
\text { component }\end{array}$ & WASH intervention & WASH outcome & Gender outcome & $\begin{array}{l}\text { Sex } \\
\text { disaggregated }\end{array}$ & Conclusion \\
\hline $\begin{array}{l}\text { Wilson and Chandler Lambok, } \\
\text { (1993) Indonesia }\end{array}$ & $\begin{array}{l}\text { Cross-sectional } \\
\text { study }\end{array}$ & $\begin{array}{l}57 \text { mothers, and } 102 \\
\text { children }\end{array}$ & $\begin{array}{l}\text { Frequency of } \\
\text { diarrhea }\end{array}$ & $\begin{array}{l}\text { Handwashing } \\
\text { intervention providing } \\
\text { education and soap. }\end{array}$ & $\begin{array}{l}\text { Access to hygiene } \\
\text { resources; frequency of } \\
\text { handwashing }\end{array}$ & $\begin{array}{l}\text { Conducted in } \\
\text { mothers }\end{array}$ & No & $\begin{array}{l}2 \text { years after the } \\
\text { intervention, } 8 \text { in } 10 \text { mothers } \\
\text { retained using hand soap. } \\
\text { Diarrhea frequency } \\
\text { decreased by } 90 \% \text {. Before } \\
\text { the intervention, zero } \\
\text { mothers washed theirs or } \\
\text { their children's hands with } \\
\text { soap after defecation or } \\
\text { before eating. Yet, after the } \\
\text { intervention, } 56 \text { reported } \\
\text { always doing so following } \\
\text { defecation, and } 94 \% \\
\text { claimed to do so before } \\
\text { eating. }\end{array}$ \\
\hline Yeasmin et al. (2017) Bangladesh & Longitudinal & $\begin{array}{l}24 \text { adults for } \\
\text { post-interviews }\end{array}$ & $N / A$ & $\begin{array}{l}\text { A waste bin and } \\
\text { informational signs to } \\
\text { indicate how to use the } \\
\text { latrine/waste bin }\end{array}$ & $\begin{array}{l}\text { Access to improved } \\
\text { sanitation, MHM; }\end{array}$ & $\begin{array}{l}\text { Considered gender } \\
\text { differences }\end{array}$ & No & $\begin{array}{l}\text { In general, the waste bins } \\
\text { were well-accepted and } \\
\text { were reported to reduce } \\
\text { blockages. Some males } \\
\text { indicated disgust with } \\
\text { menstrual health rags in the } \\
\text { trash bins was a barrier to } \\
\text { their use by women. } \\
\text { Women likewise felt } \\
\text { disgusted when using waste } \\
\text { bins. Women possessed } \\
\text { cultural beliefs that } \\
\text { menstrual rags could serve } \\
\text { as vehicles to spread } \\
\text { disease to men. }\end{array}$ \\
\hline
\end{tabular}




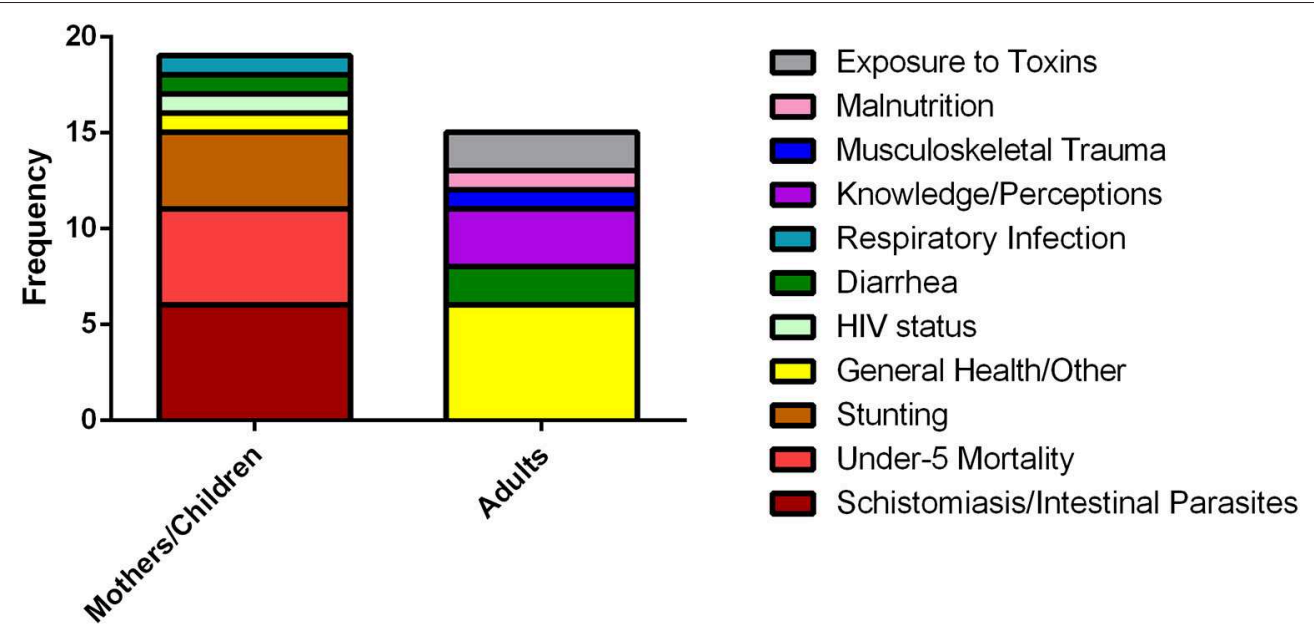

FIGURE 2 | Identified health burdens disaggregated by gender, most of which apply to health outcomes in the water-gender nexus (figure aggregated from various data sources).

factors, including the mother's BMI (Marinda et al., 2018; Prado et al., 2019), age (Dendup et al., 2018), education level (Nasr et al., 2013; Hasan and Richardson, 2017; Akachi et al., 2018; Prado et al., 2019), and lack of employment (Atalabi et al., 2016) were all found to increase the risk of disease in children.

In assessing whether women and girls were at higher risk for health burdens, most studies focused on children determining that boys were at greater risk for contracting both schistosomiasis (Kapito-Tembo et al., 2009; Ugbomoiko et al., 2009; Atalabi et al., 2016; Donohue et al., 2017) and hookworm infections (Baker et al., 2018) as well as stunting (Akombi et al., 2017) which is in line with a well-documented propensity for increased mortality among male children (World Health Organization, 2011). A single study directly analyzed the effect of gender on the frequency of waterborne diseases in adults, and found no gender differences (Al-Delaimy et al., 2014). However, numerous studies demonstrated that women's role as the primary water purveyor exposed them to multiple health risks. Women are at an increased risk of musculoskeletal disorders as a result of carrying water long-term and across long distances (Geere et al., 2018). Interestingly, males, but not females who fetched water $>15 \mathrm{~min}$, prioritized improving access to water over improving access to health services (Hunter, 2006). Women who fetched water from a drill pipe may also be at increased exposure to toxins, including lead as the blood of first-trimester pregnant women was recorded to have elevated levels of toxin lead (Guy et al., 2018). Also, how unclean water exposes households and adults more generally to toxins, such as Dichlorodiphenyldichloroethylene (DDE) and Dichloroduphenyltrichloroehtane (DDT) is documented by Gaspar et al. (2017). New mothers and pregnant women, in particular may represent a vulnerable population. For example, religious, new mothers who were fasting and did not have access to improved water or sanitation were more likely to be underweight (Desalegn et al., 2018). Furthermore, pregnant women who experienced a natural disaster reported a lack of access to basic water and maternal care which added physical and psychological stress (Sato et al., 2016).
A summary comparison of key gender, health and water differences from analyzed observational studies can be found in Table 3.

\section{Both Infrastructural and Educational Interventions Are Successful in Reducing WASH Inequities and Improving Health Outcomes}

To assess whether identified water-gender and health inequities can be addressed by currently administered interventions, we aimed to identify best practices themes from WASH interventions (Table 2). Of the 13 interventional studies included, eight examined water access, eight assessed sanitation, six assessed hygiene, and one assessed MHM. Interventions were equally split between providing WASH education $(N=8)$ or providing physical infrastructural improvements $(N=9)$. The majority of studies $(N=9)$ considered how WASH interventions could improve health impacts.

Infrastructural interventions that improved water accessibility demonstrated mixed results for long-term benefits. Filtration systems provided to women were retained by 19 to $31 \%$ after a 2-5 years follow-up (Huq et al., 2010; Pickering et al., 2017). Similarly, the use of filters corresponded to small improvements in water quality (Huq et al., 2010), and a minor reduction in the incidence of cholera (Pickering et al., 2017). However, there remained a significant depreciation in the long-term usage of the interventions (Huq et al., 2010; Pickering et al., 2017). An intervention that provided mothers with treated water was successful in reducing diarrhea in school children by $40 \%$ and was considered a feasible solution by the participating mothers (Rose et al., 2006). Hand pumps were linked with overall healthier looking children (Katsivo et al., 1993). Furthermore, a comprehensive intervention which combined hand-pumps, latrines, and hygiene education demonstrated significant success after a 7-years follow-up, drastically increasing the number of households using improved WASH practices, reducing bacteria on the hands of mothers, and consequently the incidence of diarrhea in children (Hoque et al., 1996). 
TABLE 3 | A summary of key gender differences in access to WASH and health outcomes identified from assessed observational studies.

A lack of clean water negatively

impact women and girl's quality of life

Women may have reduced water security

Women are the primary purveyors of water

\section{Sanitation and Hygiene}

Women lack access to sustainable sanitation and hygiene facilities and resources.

Women and girls were burdened by latrines which lacked privacy and security.

Male-headed households were more likely to have a household latrine.

Girls had less access than boys to hand and oral hygiene

Women and girls lack access to $\mathrm{MHM}$

\section{Gender WASH and Health}

Maternal and household access to improved WASH reduced the risk for childhood infections, stunting, and mortality.

Maternal socioeconomic, demographic, and health indicators reduce the risk for childhood disease.

Boys were at greater risk than girls for childhood disease.

Women's role as the primary water purveyor increased the risk for musculoskeletal disorders and facilitated exposure to waterbourne toxins, including heavy metals (e.g., lead),

Dichlorodiphenyldichloroethylene

(DDE) and

Dichloroduphenyltrichloroehtane (DDT).

Interventions that focused on the construction of latrines and toilets were successful in reducing the incidence of diarrhea (Chaudhuri, 2017), improving overall health (Katsivo et al., 1993), and providing more women with the privacy and safety necessary to attend to their menstrual health needs (Chaudhuri, 2017). However, while generally well-tolerated (Nyoka et al., 2017; Yeasmin et al., 2017), latrines and waste bins are associated with challenges. For example, both men and women reported feelings of disgust with menstrual rags being placed in waste bins (Yeasmin et al., 2017). Furthermore, women affected by genital mutilations had issues using latrines (Nyoka et al., 2017). As well, culture played a role in women preferring to openly defecate instead of using latrines (Nyoka et al., 2017). Hygiene-related interventions were likewise successful at alleviating disease. A face washing intervention reduced the incidence of trachoma (West et al., 1996), which had a reported higher incidence in girls than boys. Providing mothers with soap reduced diarrhea by $90 \%$ in children, as well as respiratory tract infections in school-children (Alzaher et al., 2018), and improved longterm hand hygienic practices (Wilson and Chandler, 1993; Cairncross et al., 2005).

In addition to capacity, education represents a crucial component for improving WASH and has been incorporated 
as one branch of successful multifactorial interventions, for example, to overcome cultural apprehensions and misconceptions with using latrines (Yeasmin et al., 2017). Qualitative assessments of educational interventions suggest that education can reduce the incidence of diarrhea (Williams et al., 2015) and improve overall health (Magnin et al., 2018). Evidence that women were better than men at learning sustainable WASH practices through educational interventions has also been reported (Cairncross et al., 2005; Williams et al., 2015).

\section{Assessment of Risk of Bias}

In general, the included studies showed evidence for lower levels of bias. Across the 52 assessed cross-sectional studies, $41(79 \%)$ were definitely or probably representative of the target population (Supplemental Table 1). The largest issues surrounded the reporting of participant non-response rates which was not reported by 15 studies (29\%). To our assessment, all of the six included cohort studies likewise exhibited lower levels of bias (Supplemental Table 2). Finally, one study deployed a randomized control trial to assess the effectiveness of a school intervention, which, with the exception of evidence of blinding, exhibited lower levels of bias (Supplemental Table 3).

\section{DISCUSSION}

\section{Summary of the Main Findings}

This systematic review assessed WASH-related challenges faced by women and girls and further established a clear link whereby gendered WASH inequities interconnect with health outcomes, thereby establishing the "water-gender-health" nexus. We found some indication that women may have less access to clean water (Bisung and Elliott, 2018); however, few studies have directly interrogated this question. Regardless, women and girls typically served as the main water purveyors, a role which increased their risk for musculoskeletal trauma (Geere et al., 2018), and exposure to waterborne toxins (Gaspar et al., 2017; Guy et al., 2018). Additionally, a lack of latrines that are safe, secure, and private represents a major engendered barrier. The absence of such facilities forces women and girls to avoid practicing sustainable sanitation, hygiene, and MHM due to a fear of violence, or as a result of stigmatization (Kwiringira et al., 2014; Khan et al., 2017; Budhathoki et al., 2018; Davis et al., 2018; Winter et al., 2019). Poor WASH, in general, was linked to a multitude of health burdens, and particularly childhood diseases, including schistosomiasis, under-5 mortality, and stunting (Ahmed et al., 2016; Atalabi et al., 2016; Acheampong et al., 2017, 2018; Akombi et al., 2017; Donohue et al., 2017; Vos et al., 2017; Baker et al., 2018; Marinda et al., 2018). WASH infrastructural and educational interventions in general showed promise in reducing inequities in the water-gender and related health outcome; however, issues surrounding long-term adoption reduced efficacy (Huq et al., 2010; Pickering et al., 2017).

\section{Improving WASH Is a Critical Agent for Women's Health and Empowerment}

Without explicitly searching for health-related outcomes, our search uncovered a significant overlap between WASH inequities among women and health, thereby linking the water-gender nexus with health. In support of our analysis, global reports have recognized that women and girls experience occupational hazards for waterborne diseases as a result of exposure to contaminated water and soils (World Health Organization, 2011). Irrespective of gender, the SDG six synthesis report (2018) has recognized handwashing with soap and water as a top priority for reducing disease transmission; however, gender disparities largely have not been recognized (United Nations, 2018).

Health burdens can significantly reduce human agency, for example, by reducing income and employment (Alam and Mahal, 2014). Considering that in low-resource settings women have reduced agency to make healthcare decisions, the impacts of disease and disability are likely to be further magnified (Osamor and Grady, 2016). Thus, addressing inequities in the water-gender nexus will have wider-reaching network effects, including supporting women's health, and by extension their empowerment, as outlined in various SDG five targets, including 5.c (i.e., adopt and strengthen sound policies and enforceable legislation for the promotion of gender equality and the empowerment of all women and girls at all levels). In addition, our analysis highlights a clear linkage between gender equitable access to WASH, and SDG 3.2 which aims to, by 2030, in all countries, end preventable deaths of newborns and children under 5 years of age, reduce neonatal mortality to at least as low as 12 per 1,000 live births, and to reduce under-5 mortality to at least as low as 25 per 1,000 live births. Thus, an enhanced understanding of interlinkages between water, gender, and health are increasingly relevant to, through a coordinated and integrated effort, achieving the SDGs.

\section{MHM Is a Gap in the Sustainable Development Goals} Surprisingly, our analysis identified only a limited number of studies which addressed MHM. However, given that sustainability, and linkages with the SDGs was an explicit search term, the limited number of identified papers which assessed MHM practices perhaps reflects a more significant issue that MHM is not included clearly as an indicator within the SDGs portfolio (Anjum et al., 2019). The 2018 SDG 6 Synthesis Report more broadly describes how having access to safe drinking water and WASH in schools can improve school attendance by allowing girls to meet their MHM needs (United Nations, 2018). Likewise, other systematic reviews have concretely shown the implications of MHM on promoting education and good health among adolescent girls (Sommer et al., 2016). This principle can be expanded beyond schooling and into the workplace. In Bangladesh, where four out of five factory workers are women, more than two thirds loose 6 days of work in a month because of a lack of safe places to change their menstrual pads/cloths and the absence of disposal sites. Therefore, it is quite evident that addressing MHM needs is connected with women's access/capacity to gain education, employment, and financial capacity.

Recognizing this need, in 2012, Kenya launched the Sanitary Towel program to distribute sanitary towels to girls who attended 
school to support their education and to promote health and well-being. International Organizations have recognized the importance of MHM, including the United Nations Office for Coordination of Humanitarian Affairs (UN-OCHA), through forming humanitarian response plans, and these are part of a broader goal of addressing WASH needs.

\section{Education and Long-Term Uptake Are Critical for Successful Interventions}

Our analysis of interventions to improve WASH can be successful in reducing both WASH inequities and disease; however, a focus is needed to ensure their long-term maintenance and usage. To this end, some reports indicated that women had greater levels of WASH knowledge and were better at retaining WASH-related education (Cairncross et al., 2005; Williams et al., 2015). This presents empowering women with WASH-related education as a simple, and feasible component for implementing successful interventions in the context of health and sanitationrelated challenges. This strategy has been embodied within SDG 6.b which calls for supporting and strengthening the participation of local communities in improving water and sanitation management. Our analysis supports global calls for gender mainstreaming and addressing gender inequalities in the water and WASH sectors.

\section{A Dearth of Sex-Disaggregated and Unbiased Assessments of Sustainable WASH Accessibility}

In clarifying the reliability of our identified findings, a majority of studies exhibited a lower risk of bias, often deploying appropriate sampling strategies. However, only half of studies directly compared WASH outcomes between genders, and $<10 \%$ reported at least some gender-disaggregated data. Consequently, while we report examples of gender and WASH deficiencies, it is difficult to understand how women's access to WASH services, and corresponding health effects, differ from similarly situated men.

Recognizing this problem, in 2014, the UNESCO World Water Assessment Programme (WWAP) spearheaded the formation of the "Gender and Water Toolkit" which focused on understanding and furthering the gender-water-related research and investigation through the development of new sexdisaggregated indicators to more granularly enumerate genderdisparities related to WASH. As stated by the UNESCO/WWAP, "it is not an exaggeration to say there is virtually no sexdisaggregated data on water and sanitation sectors collected by the main international agencies and groups responsible for global data compilation." The 2nd edition launched in 2019 incorporates 105 indicators in 10 different topics related to the SDGs which includes water governance, safe drinking water, sanitation and hygiene, knowledge resources, transboundary water management, water for agricultural uses, water for industry and enterprise, and human rights-based water resource management. Future investigations which explore the watergender nexus should consider gender differences and sexdisaggregated data in their WASH analyses to better identify women specific barriers, as well as to elevate problems common to all gender groups.
Water, Gender, and Health Interconnect More Broadly With Other Goals Toward Sustainable Development

The SDG 6 synthesis reports that modest progress has been made to meet the targets of the 2030 Agenda; however, a specific focus on gender issues is lacking. All 17 SDGs are explicitly and implicitly related to water, while only a fifth of SDG indicators refer to gender or sex. Nevertheless, some of the major themes encapsulated in this review directly relate to established SDGs. For example, target 6.2 that highlights the importance of hygiene and calls for special attention to the needs of women and girls. Likewise, target 3.9 calls for substantial reduction of the number of deaths and illnesses from hazardous chemicals and air, water and soil pollution and contamination, hazards which we contend represent occupational hazards for women and girls. It is also important to recognize that the interconnections that occur among SDG three, five, and six also extend to other SDGs, including; labor markets (SDG 8), political participation (SDG 10 ), poverty (SDG 1), peaceful and inclusive societies (SDG 16), among others. Future work should continue to elucidate these interactions.

\section{Moving Forward: Addressing Stigma and Promoting Gender Mainstreaming}

Gender-inequity is in part facilitated by stigma, engendered cultural norms, and a societal power imbalance. Stigma actively prevents women and girls from developing healthy habits (e.g., using soap and water or from using latrines (O'Reilly and Louis, 2014; Yeasmin et al., 2017; Winter et al., 2019). However, more than restricting access to WASH, stigma becomes an entrenched psyche, which actively promotes mental and physical distress and its pernicious effects can be readily seen with regard to MHM (Sommer et al., 2015a). For instance, girls' emotions surrounding MHM can include sadness, stress/anxiety, physical discomfort, feeling dirty, and shame, and consequently, engendered needs are often silenced (McMahon et al., 2011; Naeem et al., 2015). The stigmatization of menstruation can even result in women and girls exchanging "their bodies" for money in order to access resources for menstrual pads (Mason et al., 2013). As a result, even when capacity is available, stigma can undermine development efforts, and must be actively addressed. While methods to address stigma remain in their infancy, especially in LMICs, interventions are needed to raise awareness on the importance of engendered WASH priorities, to ensure that the needs of women and girls are underscored.

Reducing gender inequities will also inevitably require women to have a more prominent platform to advocate for the remediation of nuanced gender-barriers (Morna, 2000). In this respect, like others [Kholif and Elfarouk, 2014; Leahy et al., 2017; Dery et al., 2019; World Water Assessment Programme (UNESCO WWAP), 2019], we advocate for gendermainstreaming efforts when addressing WASH inequities. From ours and other's work it is clear that women occupy important WASH roles within households, both with fetching, storing, and using water (e.g., cleaning, cooking, washing, etc.) (Morna, 2000). Therefore, women and girls possess a particularly germane perspective which is needed to ensure that engendered WASHrelated barriers are elevated and considered by policymakers and 
decisionmakers. Including female perspectives may help elevate gender-based priorities (Dery et al., 2019), such as that when latrines are constructed, they include locks, are private, and are well-lit, in order to promote safety and therein increase access for women and girls. Thus, ensuring that a gendered perspective is included when developing capacity is essential to reducing engendered WASH inequities at scale.

Simultaneously, elevating women to leadership positions may aid in reducing cultural engendered power imbalances which actively suppress the human development of women and girls. Women and girls remain particularly disenfranchised, for example, due to their role as water purveyors and homemakers, gender roles which exacerbate the risk for health burdens (Sommer et al., 2015b; Gaspar et al., 2017; Geere et al., 2018; Guy et al., 2018), and sexual assault. Improving the status of women through gender mainstreaming represents an important first step in reducing the impact of cultural norms (UN Women, 2017). However, invariably, broader active efforts are needed to alter social behavior. While we recognize that behavioral change is a gradual process, sustainability and the empowerment of women will necessarily require efforts to break engendered cultural norms, and support the empowerment of women-critical steps to promote women's human development, and more broadly, sustainable development (Dery et al., 2019).

\section{Strengths and Limitations of the Systematic Review}

This analysis broadly combined qualitative investigation on the nuanced experiences of women with quantitative assessments on accessing sustainable WASH. While this afforded us a broad perspective on the array of WASH inequities faced by women and girls, we cannot effectively describe the magnitude of WASH deficiencies. As well, we did not exclude studies with high bias, and this limits the generalizability of our findings. We did not explicitly include keywords for health in our search strategy, which serves as a kind of prevalence calculation in order to supports broad interlinkages within the literature between gender, water, and health may limit the number of healthrelated studies identified. However, the use of the MEDLINE database likely adds a bias toward journal articles which consider health outcomes. As such, our findings should be viewed as a basis to enhance the understanding of the water-gender nexus, particularly within the sphere of related health outcomes. Finally, the search method was restricted to English, and thus, this is acknowledged as a limitation.

\section{CONCLUSIONS}

Major manifestations of the water-gender nexus include that women are burdened as a result of their role as water purveyors,

\section{REFERENCES}

Acheampong, M., Ejiofor, C., and Salinas-Miranda, A. (2017). An analysis of determinants of under-5 mortality across countries: defining priorities to a lack of private and secure latrines disproportionately impact women, and that women have less access to sustainable hygiene resources. In particular, there is a strong need for increasing MHM resources which are instrumental in supporting women's health, education, and human development. In general, we found a strong intersection between the water-gender nexus and health outcomes-the water-gender-health nexus. These include occupational health risks as a result of chronically carrying water and being exposed to contaminated water, as well as risks for infection due to poor sanitation and hygiene. Moreover, poor WASH practices among mothers are strongly linked with childhood diseases. Interventions were generally effective in reducing WASH inequities and poor health outcomes. To better understand the watergender and health interlinkages, there is a clear need for increased efforts toward sex-disaggregated data collection, as well as incorporating direct gender comparisons with respect to accessing and monitoring WASH services, and their associated health outcomes. This analysis supports the conjecture that addressing the water-gender nexus will help manage disease burdens and have a more significant impact on achieving the targets of SDGs three, five, and six in tandem.

\section{DATA AVAILABILITY STATEMENT}

The datasets generated for this study are available on request to the corresponding author.

\section{AUTHOR CONTRIBUTIONS}

$\mathrm{PP}$ and NN with contributions from MM designed the research idea and the basis of the content for the manuscript. PP conducted data extraction, analyzed the data, and wrote the manuscript. PP, NN, and MM revised, and edited the manuscript.

\section{ACKNOWLEDGMENTS}

UNU INWEH would like to acknowledge the funding and support of Global Affairs Canada to its research, policy and development mandate, programs, and projects.

\section{SUPPLEMENTARY MATERIAL}

The Supplementary Material for this article can be found online at: https://www.frontiersin.org/articles/10.3389/frwa. 2020.00006/full\#supplementary-material 
sustainable development goals: an ordinary least squares (OLS) analysis. Ann. Glob. Heal. 84, 110-120. doi: 10.29024/aogh.9

Ahmed, S. M., Alam, P. M., Rawal, L. B., Chowdhury, S. A., Murray, J., ArscottMills, S., et al. (2016). Cross-country analysis of strategies for achieving progress towards global goals for women's and children's health. Bull. World Health Organ. 94, 351-361. doi: 10.2471/BLT.15.168450

Aiemjoy, K., Stoller, N. E., Gebresillasie, S., Shiferaw, A., Tadesse, Z., Sewent, T., et al. (2017). Is using a latrine "a strange thing to do?" a mixed-methods study of sanitation preference and behaviors in rural Ethiopia. Am. J. Trop. Med. Hyg. 96, 65-73. doi: 10.4269/ajtmh.16-0541

Akachi, Y., Steenland, M., and Fink, G. (2018). Associations between key intervention coverage and child mortality: an analysis of 241 sub-national regions of sub-Saharan Africa. Int. J. Epidemiol. 47, 740-751. doi: 10.1093/ije/dyx262

Akl, E. A., Sun, X., Busse, J. W., Johnston, B. C., Briel, M., Mulla, S., et al. (2012). Specific instructions for estimating unclearly reported blinding status in randomized trials were reliable and valid. J. Clin. Epidemiol. 65, 262-267. doi: 10.1016/j.jclinepi.2011.04.015

Akombi, B. J., Agho, K. E., Hall, J. J., Merom, D., Astell-Burt, T., and Renzaho, A. M. N. (2017). Stunting and severe stunting among children under-5 years in Nigeria: a multilevel analysis. BMC Pediatr. 17:15. doi: 10.1186/s12887-016-0770-z

Alam, K., and Mahal, A. (2014). Economic impacts of health shocks on households in low and middle income countries: a review of the literature. Global. Health 10:21. doi: 10.1186/1744-8603-10-21

Al-Delaimy, A. K., Al-Mekhlafi, H. M., Nasr, N. A., Sady, H., Atroosh, W. M., Nashiry, M., et al. (2014). Epidemiology of intestinal polyparasitism among Orang Asli school children in rural Malaysia. PLoS Negl. Trop. Dis. 8:e3074. doi: 10.1371/journal.pntd.0003074

Alemu, Z. A., Ahmed, A. A., Yalew, A. W., Birhanu, B. S., and Zaitchik, B. F. (2017). Individual and community level factors with a significant role in determining child height-for-age $\mathrm{Z}$ score in East Gojjam Zone, Amhara Regional State, Ethiopia: a multilevel analysis. Arch. Public Health 75:27. doi: 10.1186/s13690-017-0193-9

Aluko, O. O., Oloruntoba, E. O., Chukwunenye, U. A., Henry, E. U., and Ojogun, E. (2018). The dynamics and determinants of household shared sanitation cleanliness in a heterogeneous urban settlement in Southwest Nigeria. Public Health 165, 125-135. doi: 10.1016/j.puhe.2018.09.013

Alzaher, A. A., Almudarra, S. S., Mustafa, M. H., and Gosadi, I. M. (2018). The importance of hand hygiene education on primary schoolgirls' absence due to upper respiratory infections in Saudi Arabia. A cluster randomized controlled trial. Saudi Med. J. 39, 1044-1049. doi: 10.15537/smj.2018.10.23344

Angoua, E. L. E., Dongo, K., Templeton, M. R., Zinsstag, J., and Bonfoh, B. (2018). Barriers to access improved water and sanitation in poor peri-urban settlements of Abidjan, Côte d'Ivoire. PLoS ONE 13:e0202928. doi: 10.1371/journal.pone.0202928

Anjum, Z., Pouramin, P., Glickman, T., and Nagabhatla, N. (2019). A synthesis report analyzing menstrual hygiene management within a humanitarian crisis. OIDA Int. J. Sustain. Dev. 12, 61-72. Available online at: https://ssrn.com/ abstract $=3481936$

Atalabi, T. E., Lawal, U., and Ipinlaye, S. J. (2016). Prevalence and intensity of genito-urinary schistosomiasis and associated risk factors among junior high school students in two local government areas around Zobe Dam in Katsina State, Nigeria. Parasit. Vectors 9:388. doi: 10.1186/s13071-016-1672-5

Baker, J. M., Trinies, V., Bronzan, R. N., Dorkenoo, A. M., Garn, J. V., Sognikin, S., et al. (2018). The associations between water and sanitation and hookworm infection using cross-sectional data from Togo's national deworming program. PLoS Negl. Trop. Dis. 12:e0006374. doi: 10.1371/journal.pntd.0006374

Bisung, E., and Elliott, S. J. (2018). Improvement in access to safe water, household water insecurity, and time savings: a cross-sectional retrospective study in Kenya. Soc. Sci. Med. 200, 1-8. doi: 10.1016/j.socscimed.2018.01.001

Bornman, M., Schlemmer, L., van der Walt, T., van Dyk, C., and Bouwman, H. (2012). Implications for health education and intervention strategies arising from children's caregivers concerns following successful malaria control. Trans. R. Soc. Trop. Med. Hyg. 106, 408-414. doi: 10.1016/j.trstmh.2012.04.007

Braxton, M. E., and Larson, K. L. (2019). In sickness and health: views on child health from a Mayan village. J. Transcultural Nurs. 30, 242-249. doi: $10.1177 / 1043659618794845$
Budhathoki, S. S., Bhattachan, M., Castro-Sánchez, E., Sagtani, R. A., Rayamajhi, R. B., Rai, P., et al. (2018). Menstrual hygiene management among women and adolescent girls in the aftermath of the earthquake in Nepal. BMC Womens. Health 18:33. doi: 10.1186/s12905-018-0527-y

Cairncross, S., Shordt, K., Zacharia, S., and Govindan, B. K. (2005). What causes sustainable changes in hygiene behaviour? A cross-sectional study from Kerala, India. Soc. Sci. Med. 61, 2212-2220. doi: 10.1016/J.SOCSCIMED.2005.04.019

Chaudhuri, I. N. (2017). Community mobilization for slum upgrading through sanitation in roma informal settlements in the Paris region. Front. Public Heal. 5:213. doi: 10.3389/fpubh.2017.00213

Davis, J., Macintyre, A., Odagiri, M., Suriastini, W., Cordova, A., Huggett, C., et al. (2018). Menstrual hygiene management and school absenteeism among adolescent students in Indonesia: evidence from a cross-sectional school-based survey. Trop. Med. Int. Heal. 23, 1350-1363. doi: 10.1111/tmi.13159

Dendup, T., Zhao, Y., and Dema, D. (2018). Factors associated with under-five mortality in Bhutan: an analysis of the Bhutan National Health Survey 2012. BMC Public Health 18:1375. doi: 10.1186/s12889-018-6308-6

Dery, F., Bisung, E., Dickin, S., and Dyer, M. (2019). Understanding empowerment in water, sanitation, and hygiene (WASH): a scoping review. J. Water Sanit. Hyg. Dev. 10, 5-15. doi: 10.2166/washdev.2019.077

Desalegn, B. B., Lambert, C., Riedel, S., Negese, T., and Biesalski, H. K. (2018). Ethiopian orthodox fasting and lactating mothers: longitudinal study on dietary pattern and nutritional status in rural tigray, Ethiopia. Int. J. Environ. Res. Public Health 15:1767. doi: 10.3390/ijerph15081767

Doherty, T., Chopra, M., Jackson, D., Goga, A., Colvin, M., and Persson, L.-A. (2007). Effectiveness of the WHO/UNICEF guidelines on infant feeding for HIV-positive women: results from a prospective cohort study in South Africa. AIDS 21, 1791-1797. doi: 10.1097/QAD.0b013e32827b1462

Donohue, R. E., Mashoto, K. O., Mubyazi, G. M., Madon, S., Malecela, M. N., and Michael, E. (2017). Biosocial determinants of persistent schistosomiasis among schoolchildren in Tanzania despite repeated treatment. Trop. Med. Infect. Dis. 2:e61. doi: 10.3390/tropicalmed2040061

Fletcher, A. J., and Schonewille, R. (2015). United Nations World Water Assessment Programme Gender and Water Series Resource Paper United Nations World Water Assessment Programme. Available online at: http://www.unesco.org/ open-access/

Fuge, T. G., Ayanto, S. Y., and Gurmamo, F. L. (2015). Assessment of knowledge, attitude and practice about malaria and ITNs utilization among pregnant women in Shashogo District, Southern Ethiopia. Malaria J. 14:235. doi: 10.1186/s12936-015-0755-7

Gaspar, F. W., Chevrier, J., Quirós-Alcalá, L., Lipsitt, J. M., Barr, D. B., Holland, N., et al. (2017). Levels and determinants of DDT and DDE exposure in the VHEMBE cohort. Environ. Health Perspect. 125:077006. doi: 10.1289/E HP353

Geere, J.-A., Bartram, J., Bates, L., Danquah, L., Evans, B., Fisher, M. B., et al. (2018). Carrying water may be a major contributor to disability from musculoskeletal disorders in low income countries: a crosssectional survey in South Africa, Ghana and Vietnam. J. Glob. Health 8:010406. doi: 10.7189/jogh.08.010406

Guy, M., Accrombessi, M., Fievet, N., Yovo, E., Massougbodji, A., Le Bot, B., et al. (2018). Toxics ( $\mathrm{Pb}, \mathrm{Cd}$ ) and trace elements ( $\mathrm{Zn}, \mathrm{Cu}$, $\mathrm{Mn})$ in women during pregnancy and at delivery, South Benin, 2014-2015. Environ. Res. 167, 198-206. doi: 10.1016/J.ENVRES.2018. 06.054

Hall, D. C., and Le, Q. B. (2018). Factors influencing mitigation of risk of waterborne disease in Vietnam among small scale integrated livestock farmers. Front. Veterin. Sci. 5:154. doi: 10.3389/fvets.2018.00154

Hasan, M. M., and Richardson, A. (2017). How sustainable household environment and knowledge of healthy practices relate to childhood morbidity in South Asia: analysis of survey data from Bangladesh, Nepal and Pakistan. BMJ Open 7: e015019. doi: 10.1136/bmjopen-2016-015019

Holvoet, N., Dewachter, S., and Molenaers, N. (2016). Look who's talking. explaining water-related information sharing and demand for action among ugandan villagers. Environ. Manage. 58, 780-796. doi: 10.1007/s00267-01 6-0760-9

Hoque, B. A., Juncker, T., Sack, R. B., Ali, M., and Aziz, K. M. (1996). Sustainability of a water, sanitation and hygiene education project in rural Bangladesh: a 5-year follow-up. Bull. World Health Organ. 74, 431-437. 
Hunter, L. M. (2006). Household strategies in the face of resource scarcity in coastal Ghana: are they associated with development priorities? Popul. Res. Policy Rev. 25, 157-174. doi: 10.1007/s11113-006-9002-9

Huq, A., Yunus, M., Sohel, S. S., Bhuiya, A., Emch, M., Luby, S. P., et al. (2010). Simple sari cloth filtration of water is sustainable and continues to protect villagers from Cholera in Matlab, Bangladesh. MBio 1:e00034-10. doi: 10.1128/mBio.00034-10

Inobaya, M. T., Chau, T. N., Ng, S. K., MacDougall, C., Olveda, R. M., Tallo, V. L., et al. (2018). Mass drug administration and the sustainable control of schistosomiasis: an evaluation of treatment compliance in the rural Philippines. Parasites and Vectors 11:441. doi: 10.1016/j.ijid.2017. 10.023

Kapito-Tembo, A. P., Mwapasa, V., Meshnick, S. R., Samanyika, Y., Banda, D., Bowie, C., et al. (2009). Prevalence distribution and risk factors for Schistosoma hematobium infection among school children in Blantyre, Malawi. PLoS Negl. Trop. Dis. 3:e361. doi: 10.1371/journal.pntd.0000361

Katsivo, M. N., Muthami, L. N., Karama, M., and Kingori, F. (1993). Perception of a schistosomiasis control project in rural Kenya by the beneficiaries. East Afr. Med. J. 70, 613-616.

Khan, S. M., Bain, R. E. S., Lunze, K., Unalan, T., Beshanski-Pedersen, B., Slaymaker, T., et al. (2017). Optimizing household survey methods to monitor the Sustainable Development Goals targets 6.1 and 6.2 on drinking water, sanitation and hygiene: a mixed-methods field-test in Belize. PLoS ONE 12:e0189089. doi: 10.1371/journal.pone.0189089

Kholif, M. T., and Elfarouk, A. M. (2014). Activating the role of women in water projects. Water Sci. 28, 75-82. doi: 10.1016/j.wsj.2014.10.002

Kwiringira, J., Atekyereza, P., Niwagaba, C., and Günther, I. (2014). Descending the sanitation ladder in urban Uganda: evidence from Kampala Slums. BMC Public Health 14:624. doi: 10.1186/1471-2458-14-624

Leahy, C., Winterford, K., Nghiem, T., Kelleher, J., Leong, L., and Willetts, J. (2017). Transforming gender relations through water, sanitation, and hygiene programming and monitoring in Vietnam. Gend. Dev. 25, 283-301. doi: 10.1080/13552074.2017.13 31530

Lubon, A. J., Erchick, D. J., Khatry, S. K., LeClerq, S. C., Agrawal, N. K., Reynolds, M. A., et al. (2018). Oral health knowledge, behavior, and care seeking among pregnant and recently-delivered women in rural Nepal: a qualitative study. BMC Oral Health 18:97. doi: 10.1186/s12903-018-0564-9

Magnin, M., Jeannot, E., Voahangy, R., and Stoll, B. (2018). A realistic evaluation approach highlighted the success factors and difficulties of an innovative and comprehensive malnutrition programme in Madagascar. Acta Paediatr. 107, 1570-1580. doi: 10.1111/apa.14267

Magnusson, L., and Bickenbach, J. (2018). Access to human rights for persons using prosthetic and orthotic assistive devices in Sierra Leone. Disability and Rehabilit. 1-8. doi: 10.1080/09638288.2018.1515267

Mahamud, A. S., Ahmed, J. A., Nyoka, R., Auko, E., Kahi, V., Ndirangu, J., et al. (2011). Epidemic cholera in Kakuma Refugee Camp, Kenya, 2009: the importance of sanitation and soap. J. Infect. Dev. Ctries. 6, 234-241. doi: 10.3855/jidc. 1966

Marinda, P. A., Genschick, S., Khayeka-Wandabwa, C., Kiwanuka-Lubinda, R., and Thilsted, S. H. (2018). Dietary diversity determinants and contribution of fish to maternal and under-five nutritional status in Zambia. PLoS ONE 13:e0204009. doi: 10.1371/journal.pone.0204009

Mason, L., Nyothach, E., Alexander, K., Odhiambo, F. O., Eleveld, A., Vulule, J., et al. (2013). "We keep it secret so no one should know"-a qualitative study to explore young schoolgirls attitudes and experiences with menstruation in rural Western Kenya. PLoS ONE 8:e79132. doi: 10.1371/journal.pone.0079132

McMahon, S. A., Winch, P. J., Caruso, B. A., Ogutu, E. A., Ochari, I. A., and Rheingans, R. D. (2011). "The girl with her period is the one to hang her head" reflections on menstrual management among schoolgirls in rural Kenya. $B M C$ Int. Health Hum. Rights 11:7. doi: 10.1186/1472-698X-11-7

Morna, C. (2000). Mainstreaming gender in water and sanitation: literature review for the SA department of water and sanitation. Gend. Links 1-35. Available online at: http://www.gdrc.org/uem/water/gender/genderingwatersanitation. pdf

Naeem, K., Klawitter, S., and Aziz, A. (2015). Learning, acting, and learning (LAL) research on schools' menstrual hygiene management (MHM): Pakistan. Waterlines 34, 103-112. doi: 10.3362/1756-3488.2015.010
Nagabhatla, N., Avellan, T., Pouramin, P., Qadir, M., Mehta, P., Payne, J., et al. (2019). UNESCO world water assessment programme (WWAP). The United Nations World Water Development Report 2019: Leaving No One Behind (Paris: UNESCO) p. 44-57.

Nasr, N. A., Al-Mekhlafi, H. M., Ahmed, A., Roslan, M. A., and Bulgiba, A. (2013). Towards an effective control programme of soil-transmitted helminth infections among Orang Asli in rural Malaysia. Part 2: Knowledge, attitude, and practices. Parasit. Vectors 6:28. doi: 10.1186/1756-3305-6-28

Njuguna, J. (2019). Progress in sanitation among poor households in Kenya: evidence from demographic and health surveys. BMC Public Health 19:135. doi: 10.1186/s12889-019-6459-0

Nyoka, R., Foote, A. D., Woods, E., Lokey, H., O’Reilly, C. E., Magumba, F., et al. (2017). Sanitation practices and perceptions in Kakuma refugee camp, Kenya: comparing the status quo with a novel service-based approach. PLoS ONE 12:e0180864. doi: 10.1371/JOURNAL.PONE.0180864

Oberoi, S. S., Mohanty, V., Mahajan, A., and Oberoi, A. (2014). Evaluating awareness regarding oral hygiene practices and exploring gender differences among patients attending for oral prophylaxis. J. Indian Soc. Periodontol. 18, 369-374. doi: 10.4103/0972-124X.134580

Odetola, T. D., and Fakorede, E. O. (2018). Assessment of perinatal care satisfaction amongst mothers attending postnatal care in Ibadan, Nigeria. Annals of Global Health 84:36. doi: 10.29024/aogh.10

O'Reilly, K., and Louis, E. (2014). The toilet tripod: Understanding successful sanitation in rural India. Health and Place 29, 43-51. doi: 10.1016/j.healthplace.2014.05.007

Osamor, P. E., and Grady, C. (2016). Women's autonomy in health care decisionmaking in developing countries: a synthesis of the literature. Int. J. Womens. Health 8, 191-202. doi: 10.2147/IJWH.S105483

Pickering, A. J., Arnold, B. F., Dentz, H. N., Colford, J. M. Jr., and Null, C. (2017). Climate and health co-benefits in low-income countries: a case study of carbon financed water filters in Kenya and a call for independent monitoring. Environ. Health Perspect. 125:278. doi: 10.1289/EHP342

Prado, E. L., Yakes Jimenez, E., Vosti, S., Stewart, R., Stewart, C. P., Somé, J., et al. (2019). Path analyses of risk factors for linear growth faltering in four prospective cohorts of young children in Ghana, Malawi and Burkina Faso. BMJ Glob. Heal. 4:e001155. doi: 10.1136/bmigh-2018-001155

Rose, A., Roy, S., Abraham, V., Holmgren, G., George, K., Balraj, V., et al. (2006). Solar disinfection of water for diarrhoeal prevention in southern India. Arch. Dis. Child. 91, 139-141. doi: 10.1136/adc.2005.077867

Sato, M., Nakamura, Y., Atogami, F., Horiguchi, R., Tamaki, R., Yoshizawa, T., et al. (2016). Immediate needs and concerns among pregnant women during and after Typhoon Haiyan (Yolanda). PLoS Curr. 8. doi: 10.1371/currents.dis.29e4c0c810db47d7fd8d0d1fb78 $2892 \mathrm{c}$

Scott, N. A., Vian, T., Kaiser, J. L., Ngoma, T., Mataka, K., Henry, E. G., et al. (2018). Listening to the community: using formative research to strengthen maternity waiting homes in Zambia. PLoS One 13. doi: 10.1371/journal.pone.0194535

Sommer, M., Caruso, B. A., Sahin, M., Calderon, T., Cavill, S., Mahon, T., et al. (2016). A time for global action: addressing girls' menstrual hygiene management needs in schools. PLOS Med. 13:e1001962. doi: 10.1371/journal.pmed.10 01962

Sommer, M., Ferron, S., Cavill, S., and House, S. (2015b). Violence, gender and WASH: spurring action on a complex, under-documented and sensitive topic. Env. Urbanization 27, 105-116. doi: 10.1177/0956247814564528

Sommer, M., Hirsch, J. S., Nathanson, C., and Parker, R. G. (2015a). Comfortably, safely, and without shame: defining menstrual hygiene management as a public health issue. Am. J. Public Health 105, 1302-1311. doi: 10.2105/AJPH.2014.302525

Ugbomoiko, U. S., Dalumo, V., Ofoezie, I. E., and Obiezue, R. N. N. (2009). Socio-environmental factors and ascariasis infection among school-aged children in Ilobu, Osun State, Nigeria. Trans. R. Soc. Trop. Med. Hyg. 103, 223-228. doi: 10.1016/j.trstmh.2008.12.014

UN Women (2017). Gender Equality and Water, Sanitation and Hygiene, Report of the Expert Group Meeting. New York, NY. Available online at: http:// www.unwomen.org/-/media/headquarters/attachments/sections/news\%20and $\% 20$ events/stories/2018/expert-group-meeting-on-gender-equality-andwater-sanitation- and-hygiene-report-2017-12-en.pdf?la=en\&vs=5541 
United Nations (2018). Sustainable Development Goal 6: Synthesis Report on Water and Sanitation. New York, NY. doi: 10.1126/science.278.5339.827

Vos, T., Abajobir, A. A., Abate, K. H., Abbafati, C., Abbas, K. M., Abd-Allah, F., et al. (2017). Global, regional, and national incidence, prevalence, and years lived with disability for 328 diseases and injuries for 195 countries, 1990-2016: a systematic analysis for the Global Burden of Disease Study 2016. Lancet 390, 1211-1259. doi: 10.1016/S0140-6736(17)32154-2

West, S. K., Munoz, B., Lynch, M., Kayongoya, A., Mmbaga, B. B. O., and Taylor, H. R. (1996). Risk factors for constant, severe trachoma among preschool children in Kongwa, Tanzania. Am. J. Epidemiol. 143, 73-78. doi: 10.1093/oxfordjournals.aje.a008659

WHO and UNICEF (2017). Progress on Drinking Water, Sanitation, and Hygiene: 2017 Update and SDG Baselines. Geneva.

WHO and UNICEF (2019). Progress on Household Drinking Water, Sanitation, and Hygiene 2000-2017: Special Focus on Inequalities. New York, NY.

Williams, H. A., Gaines, J., Patrick, M., Berendes, D., Fitter, D., and Handzel, T. (2015). Perceptions of health communication, water treatment and sanitation in artibonite department, Haiti, March-April 2012. PLoS ONE 10:e0142778. doi: 10.1371/journal.pone.0142778

Wilson, J. M., and Chandler, G. N. (1993). Sustained improvements in hygiene behaviour amongst village women in lombok, indonesia. Trans. R. Soc. Trop. Med. Hyg. 87, 615-616. doi: 10.1016/0035-9203(93)90260-W

Winter, S., Dreibelbis, R., and Barchi, F. (2019). Women's sanitation practices in informal settlements: a multi-level analysis of factors influencing utilisation in Nairobi, Kenya. Glob. Public Health 14, 663-674. doi: 10.1080/17441692.2018.1534256
World Health Organization (2011). Taking Sex and Gender Into Account in Emerging Infectious Disease Programmes: An Analytical Framework. Available online at: http://iris.wpro.who.int/handle/10665.1/7977 (accessed December 27, 2019).

World Water Assessment Programme (UNESCO WWAP) (2019). Toolkit on Sex-disaggregated Water Data. Available online at: http:// www.unesco.org/new/en/natural-sciences/environment/water/wwap/

water-and-gender/methodology-indicators-and-toolkit/ (accessed December 4, 2019).

Yeasmin, F., Luby, S. P., Saxton, R. E., Nizame, F. A., Alam, M.-U., Dutta, N. C., et al. (2017). Piloting a low-cost hardware intervention to reduce improper disposal of solid waste in communal toilets in low-income settlements in Dhaka, Bangladesh. BMC Public Health 17:682. doi: 10.1186/s12889-0174693-x

Conflict of Interest: The authors declare that the research was conducted in the absence of any commercial or financial relationships that could be construed as a potential conflict of interest.

Copyright (C) 2020 Pouramin, Nagabhatla and Miletto. This is an open-access article distributed under the terms of the Creative Commons Attribution License (CC BY). The use, distribution or reproduction in other forums is permitted, provided the original author(s) and the copyright owner(s) are credited and that the original publication in this journal is cited, in accordance with accepted academic practice. No use, distribution or reproduction is permitted which does not comply with these terms. 